\title{
Arbeid van vrouwen in Limburg in de twintigste eeuw
}

Citation for published version (APA):

Knotter, A. (2018). Arbeid van vrouwen in Limburg in de twintigste eeuw: een stille revolutie. WBOOKS/Sociaal Historisch Centrum voor Limburg. https://doi.org/10.26481/spe.20181130ak

Document status and date:

Published: 01/01/2018

DOI:

10.26481/spe.20181130ak

Document Version:

Publisher's PDF, also known as Version of record

\section{Please check the document version of this publication:}

- A submitted manuscript is the version of the article upon submission and before peer-review. There can be important differences between the submitted version and the official published version of record.

People interested in the research are advised to contact the author for the final version of the publication, or visit the DOI to the publisher's website.

- The final author version and the galley proof are versions of the publication after peer review.

- The final published version features the final layout of the paper including the volume, issue and page numbers.

Link to publication

\footnotetext{
General rights rights.

- You may freely distribute the URL identifying the publication in the public portal. please follow below link for the End User Agreement:

www.umlib.nl/taverne-license

Take down policy

If you believe that this document breaches copyright please contact us at:

repository@maastrichtuniversity.nl

providing details and we will investigate your claim.
}

Copyright and moral rights for the publications made accessible in the public portal are retained by the authors and/or other copyright owners and it is a condition of accessing publications that users recognise and abide by the legal requirements associated with these

- Users may download and print one copy of any publication from the public portal for the purpose of private study or research.

- You may not further distribute the material or use it for any profit-making activity or commercial gain

If the publication is distributed under the terms of Article $25 \mathrm{fa}$ of the Dutch Copyright Act, indicated by the "Taverne" license above, 


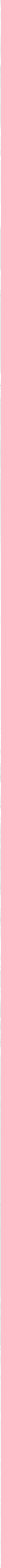





\section{ARBEID VAN VROUWEN IN LIMBURG IN DE TWINTIGSTE EEUW: EEN STILLE REVOLUTIE}

Rede in verkorte vorm uitgesproken op vrijdag 30 november 2018 bij het afscheid als hoogleraar op de door het Sociaal Historisch Centrum voor Limburg ingestelde leerstoel 'Vergelijkende regionale geschiedenis, in het bijzonder die van Limburg en aangrenzende regio's' aan de Faculteit der Cultuur-en Maatschappijwetenschappen van de Universiteit Maastricht

Ad Knotter 
Ad Knotter

ARBEID VAN VROUWEN IN LIMBURG IN DE TWINTIGSTE EEUW:EEN STILLE REVOLUTIE 


\section{Het ontbrekende hoofdstuk}

Mevrouw de (pro)rector, geacht bestuur van het Sociaal Historisch Centrum voor Limburg, zeer gewaardeerde toehoorders,

Ter gelegenheid van het 150-jarig bestaan in 2013 had het Limburgs Geschied-en Oudheidkundig Genootschap de moed een nieuwe wetenschappelijke geschiedenis van Limburg uit te brengen onder de te bescheiden titel: Limburg: een geschiedenis. Ik had de eer deel uit te maken van de redactie. Voor dit driedelige werk werd ervoor gekozen om experts op deelterreinen van de Limburgse geschiedenis aan het woord te laten over hun specifieke terrein van onderzoek. Deze opzet leidde ertoe dat de hoofdstukken vaak van hoge kwaliteit waren, maar dat er onvermijdelijk ook lacunes bleven. Als één van die lacunes werd door de redactie zelf vastgesteld:

de geschiedenis van de Limburgse vrouw, of beter: de gender-verhoudingen. Idealiter zouden deze in elk hoofdstuk moeten worden gethematiseerd, maar door het gebrek aan voorstudies was dit niet altijd mogelijk. Evenmin kon een historicus of historica worden gevonden die in staat was althans een hoofdstuk over dit onderwerp te schrijven. ${ }^{1}$

In gesprekken die ik als redactielid met potentiële auteurs over dit thema voerde, kwam steeds als argument of rechtvaardiging naar voren dat een aparte studie over vrouwen eigenlijk achterhaald was en dat de gender-verhoudingen in alle vormen van geschiedschrijving aan de orde zouden moeten komen. Dat moge zo zijn, maar dat neemt toch niet weg dat er specifiek over de rol van vrouwen wel degelijk apart en interessant onderzoek mogelijk en noodzakelijk is. In deze afscheidsrede neem ik die uitdaging aan en wil ik laten zien dat er op mijn eigen onderzoeksterrein, dat van arbeid en beroep, over de geschiedenis van vrouwen in Limburg veel belangwekkends is te vertellen.

\section{Een stille revolutie}

Voor velen is het misschien een verrassing dat de vrouwelijke arbeidsparticipatie in Limburg in de loop van de twintigste eeuw is geëvolueerd van een relatief hoog

1 Louis Berkvens, Arnoud-Jan Bijsterveld, Ad Knotter, Paul Tummers, Leo Wessels (red.), Limburg: een geschiedenis, deel III:vanaf 1800 (Maastricht 2015) 20. 
niveau naar een relatief laag niveau - relatief wil in dit verband zeggen: in vergelijking met Nederland als geheel. ${ }^{2} \mathrm{U}$ ziet dit in grafiek 1 , waarin de verschillen met Nederland zijn weergegeven.

Grafiek 1. Het verschil in vrouwelijke arbeidsparticipatie in Limburg en Nederland, 18891991 (procentpunten)

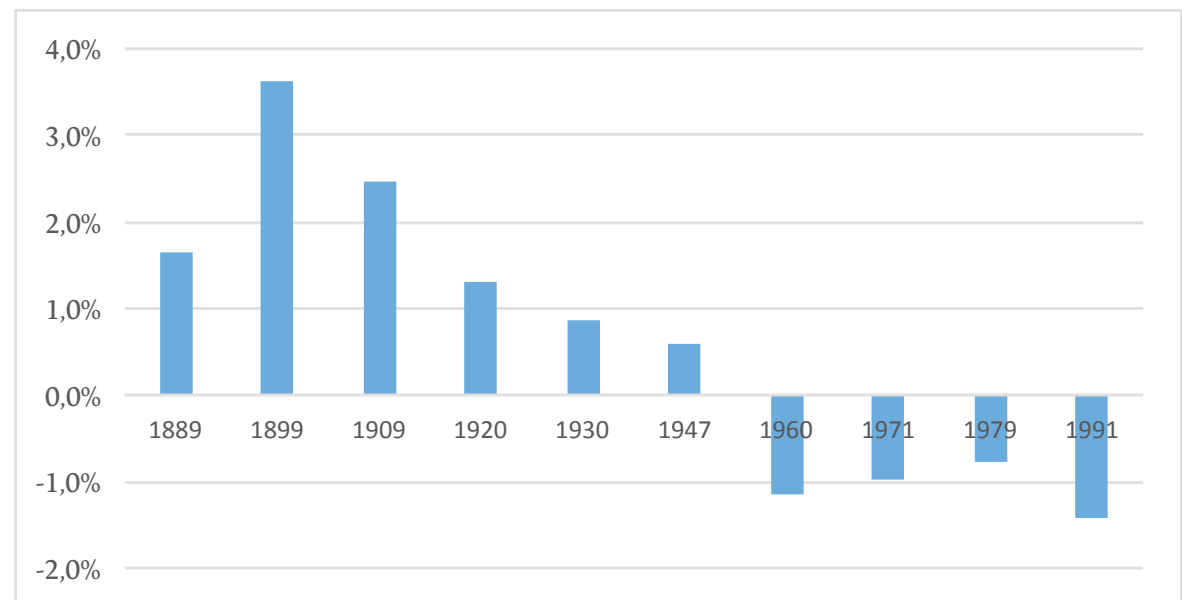

NB 'Vrouwelijke arbeidsparticipatie' gedefinieerd als het aantal vrouwen met een geteld beroep ten opzichte van de totale vrouwelijke bevolking.

Bronnen: Beroepstellingen 1889-1971; CBS, Regionaal statistisch zakboek, 1982 en 1993.

Uit de grafiek blijkt, ten eerste, dat er tot halverwege de twintigste eeuw naar verhouding meer vrouwen in Limburg een beroep uitoefenden dan in Nederland als geheel, ten tweede, dat deze Limburgse voorsprong in de eerste helft van de twintigste eeuw geleidelijk daalde om, ten derde, in de jaren 1950 om te slaan in een achterstand wat betreft de vrouwelijke arbeidsparticipatie. Dit is wat ik bedoel met 'de stille revolutie' in de titel van mijn voordracht. In het nu volgende zal ik deze stille revolutie nader analyseren door in te zoomen op specifieke beroepscategorieën en lokale verschillen.

2 Zie voor het relatief hoge aandeel van werkende vrouwen in Limburg (en Noord-Brabant) in de beroepstelling van 1909 ook Theo Engelen en Petra Kalkman, 'Vrouwenarbeid en zijn demografische achtergronden. Een momentopname in Nederland anno 1909', Tijdschrift voor Sociale Geschiedenis 17 (1991) 295-323. 


\section{Wat is vrouwelijke arbeidsparticipatie?}

Maar voor ik dat ga doen moet ik eerst iets zeggen over het begrip 'vrouwelijke arbeidsparticipatie'. De definitie en de meting daarvan zijn namelijk helemaal niet vanzelfsprekend. In grafiek 1 wordt de arbeidsparticipatie gemeten aan de hand van beroepstellingen, maar met name waar het gaat om arbeid van vrouwen is het belangrijk om te beseffen dat het hebben van een beroep niet hetzelfde is als het verrichten van arbeid. Een beroep is een identiteit die aan een persoon wordt toegeschreven, door zichzelf of door anderen, anders gezegd: een conventie over welke arbeid als beroep wordt gewaardeerd. Voor arbeid door vrouwen, zeker als die in gezinsverband wordt uitgeoefend, is dat lang niet altijd het geval. Ook arbeid door vrouwen buiten het gezin werd en wordt vaak niet als een 'beroep' beschouwd. Er is daarom consensus onder historici van de vrouwenarbeid dat beroepstellingen en andere vormen van beroepenregistratie de omvang daarvan systematisch onderschatten. ${ }^{3}$

Ik kan dat illustreren met drie Limburgse voorbeelden in sectoren die hierna nog uitgebreider aan de orde zullen komen: de Maastrichtse aardewerkindustrie, de landbouw, en de mijnbouw. In zijn dissertatie over het Boschstraatkwartier in Maastricht kon Thijs van Vugt de beroepsvermeldingen van bij de glas-en aardewerkfabrieken van de Sphinx werkzame vrouwen in het bevolkingsregister systematische vergelijken met die in de personeelsadministratie van het bedrijf. Van 417 van de 455 vrouwen die per 1 januari 1880 stonden ingeschreven in het personeelsregister werd geen beroep vermeld in het bevolkingsregister, dat is 92 procent; in 1905 was dat het geval bij 186 van de 253 bij Sphinx werkzame vrouwen, dat is 74 procent. ${ }^{4} \mathrm{Nu}$ gaat het hier om beroepsvermeldingen in het bevolkingsregister en niet om een beroepstelling, maar deze verschillen geven wel aan hoe weinig deze arbeid door registrerende gemeenteambtenaren, en mogelijk ook door deze vrouwen zelf, daadwerkelijk als een beroep werd beschouwd.

Een tweede voorbeeld betreft de door vrouwen verrichtte arbeid in de landbouw in het Noord-Limburgse landbouwdorp Horst in de jaren 1950..$^{5}$ In de

3 Vgl. Jane Humphries en Carmen Sarasúa, 'Off the Record: Reconstructing Women's Labor Force Participation in the European Past', Feminist Economics 18:4 (2012) 39-67. Voor Nederland: Ariadne Schmidt en Elise van Nederveen Meerkerk, 'Reconsidering The "First Male-Breadwinner Economy": Women's Labor Force Participation in The Netherlands, 1600-1900', Feminist Economics 18:4 (2012) 6996, aldaar 79-89; Corrie van Eijl, Het werkzame verschil.Vrouwen in de slag om arbeid 1898-1940 (Hilversum 1994) 39-46, met verschillende voorbeelden van ondertelling in de beroepstellingen.

4 Thijs van Vugt, Een arbeidersbuurt onder de rook van 'De Sphinx'. Een sociaal-ruimtelijke geschiedenis van het Boschstraatkwartier-Oost te Maastricht (Hilversum 2015) 83.

5 Ontleend aan Esther Jacobs, 'De arbeid van ongehuwde vrouwen in mijnwerkers- en boerengezinnen. Een onderzoek in de Limburgse gemeenten Stein en Horst in de jaren 1950', Studies over de sociaalecono- 
beroepstelling van 1960 werden in die gemeente 83 in de landbouw werkende vrouwen geteld, maar uit een in 1955 gehouden arbeidsenquête bleek dat alleen al 369 van de 548 ondervraagde boerendochters thuis een vorm van agrarische arbeid verrichtten, meestal in combinatie met huishoudelijke werkzaamheden. De landbouwtelling van 1956 meldde 808 meewerkende vrouwelijke gezinsleden in de landbouw in Horst, ook in dit geval grotendeels part time naast werk in het huishouden. Door deze arbeid leverden deze vrouwen in economische zin wel degelijk een belangrijke bijdrage aan het reilen en zeilen van het gezinsbedrijf, maar zij werden niet als werkzaam in de landbouw opgenomen in de beroepstelling van 1960.

Het derde voorbeeld betreft de mijnindustrie. In deze sector bestond een zeer strikte scheiding tussen loonarbeid door de mannelijke gezinsleden in de mijn en huishoudelijke arbeid door de vrouwen in het gezin. ${ }^{6}$ Die was volledig gewijd aan de zorg voor het huishouden en alles wat nodig was om het de mannen mogelijk te maken hun zware en onregelmatige arbeid in de mijn te verrichten. Het huishouden moest worden aangepast aan de wisselende diensten van de man en de werkende zoons. Het koken op verschillende tijden, het wassen van de mijnkleding, het opvoeden van de kinderen, vereisten een voortdurende en flexibele arbeidsinzet van de mijnwerkersvrouw, waar mogelijk ondersteund door opgroeiende dochters. Overspannenheid kwam regelmatig voor, zo vaak dat het Algemeen Mijnwerkersfonds speciaal plaatsen reserveerde in een rusthuis voor arbeidersvrouwen, het dr. Poelsoord bij Maastricht. ${ }^{7}$ De mijnwerkersvrouwen werkten zich zogezegd uit de naad, maar hun arbeid werd niet als beroep herkend en benoemd.

Ondanks deze tekortkomingen zal ik mij in wat volgt niettemin grotendeels baseren op tellingen van beroepen, voornamelijk in de officiële beroepstellingen. Omdat ik daarbij steeds vergelijkend tewerk zal gaan tussen regio's en bedrijfstakken, kan het bezwaar van onderregistratie deels worden weggenomen, voor zover we tenminste kunnen veronderstellen dat de onderregistratie van vrouwenarbeid overal in gelijke mate voorkwam, dus in het voorbeeld van grafiek 1 dat die in het hele land naar verhouding net zo groot was als die in Limburg. Dat is helemaal niet zeker, en waar mogelijk zal ik de gegevens uit de beroepstellingen kritisch onder de loep nemen, maar we hebben weinig andere betrouwbare en systematische bronnen over arbeid. Voor dit verhaal zullen we het ermee moeten doen.

mische geschiedenis van Limburg/Jaarboek van het Sociaal Historisch Centrum voor Limburg LXII (2017) 76-100, aldaar 85-91.

6 Vgl. Willibrord Rutten, 'Het thuisfront van de mijnwerker', in: Ad Knotter (red.), Mijnwerkers in Limburg. Een sociale geschiedenis (Nijmegen 2012) 388-424.

7 Paul Arnold, “'Een zegen voor onze gezinnen”. Het Dr. Poelsoord, een historische schets van een opmerkelijke instelling', Studies over de sociaaleconomische geschiedenis van Limburg/Jaarboek van het Sociaal Historisch Centrum voor Limburg XLI (1996) 1-77. 


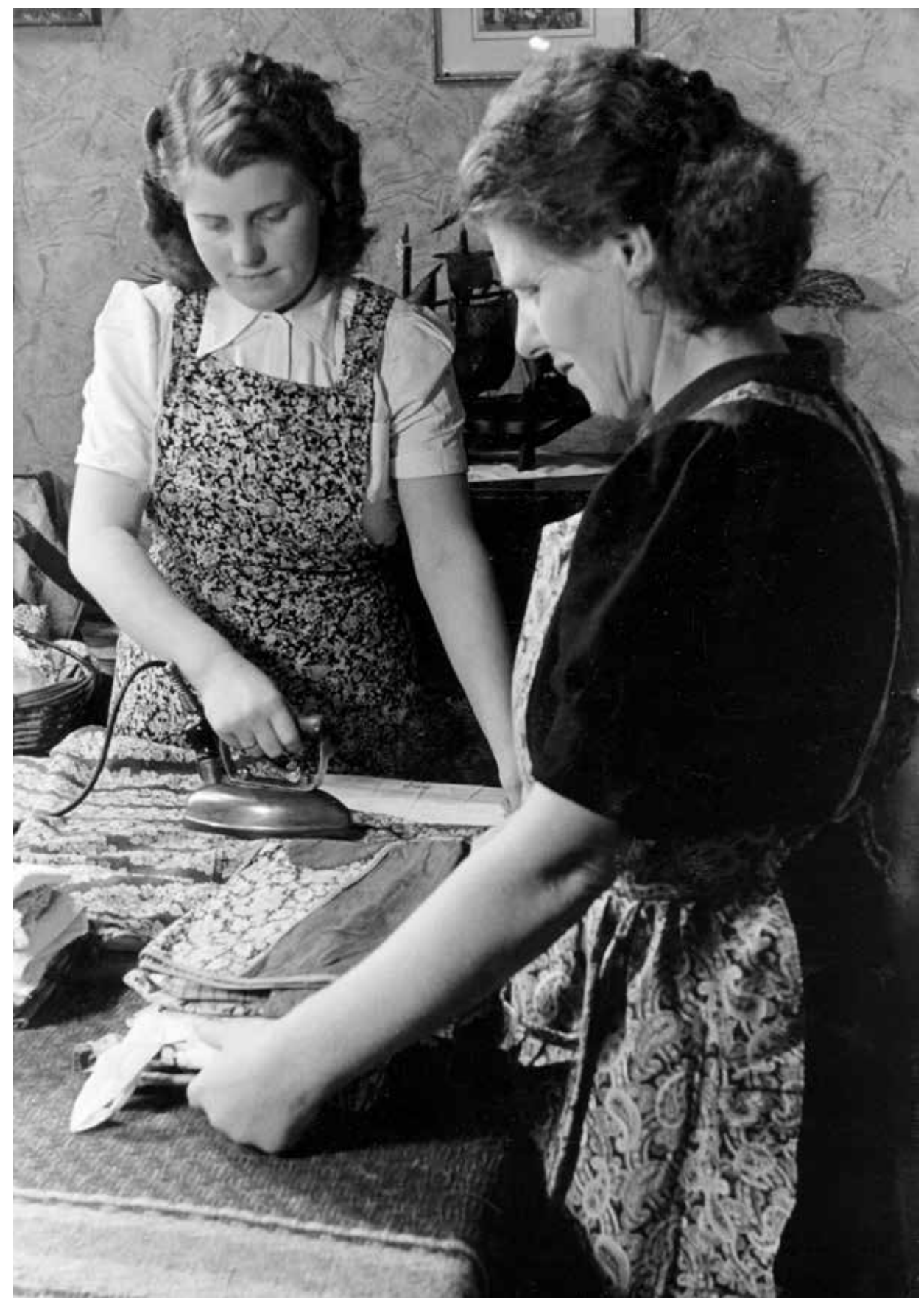

Afbeelding 1. Mijnwerkersvrouw Van Eyk en haar dochter aan het werk in het huishouden, 1947. RHCL, fotocollectie Staatsmijnen/DSM. 


\section{Verschillen tussen Limburg en Nederland per beroeps- categorie}

Als eerste stap in de verklaring voor de relatief hoge vrouwelijke arbeidsparticipatie in Limburg heb ik de vrouwelijke beroepsbevolking uitgesplitst naar economische sector en vergeleken met die in Nederland als geheel (grafiek 2). Daaruit blijkt dat die gedurende de gehele periode van overwicht, dus tot en met de telling van 1947, grotendeels kan worden toegeschreven aan het werk van vrouwen in de landbouwsector. Tot het begin van de twintigste eeuw waren vrouwen in Limburg ook oververtegenwoordigd in de industrie, maar in de beroepstellingen na die van 1909, met name die in de jaren 1920, 1930 en 1940, waren er naar verhouding juist minder Limburgse vrouwen werkzaam in de industrie. Dat is een gevolg van het grote belang van de mijnindustrie in die periode, waarin vrijwel geen vrouwen werkten. De dienstensector is wat betreft de deelname van vrouwen gedurende de gehele periode ondervertegenwoordigd in Limburg. Hieronder zal blijken dat deze verschillen per sector ook zichtbaar zijn in een grote regionale verscheidenheid in vrouwelijke arbeidsparticipatie in Limburg (althans tot de jaren 1950): hoog in de landbouwdorpen en in de Maastrichtse industrie, laag in de mijnbouwgebieden.

Grafiek 2. Het verschil in vrouwelijke arbeidsparticipatie in Limburg en Nederland per sector, 1889-1971 (procentpunten)

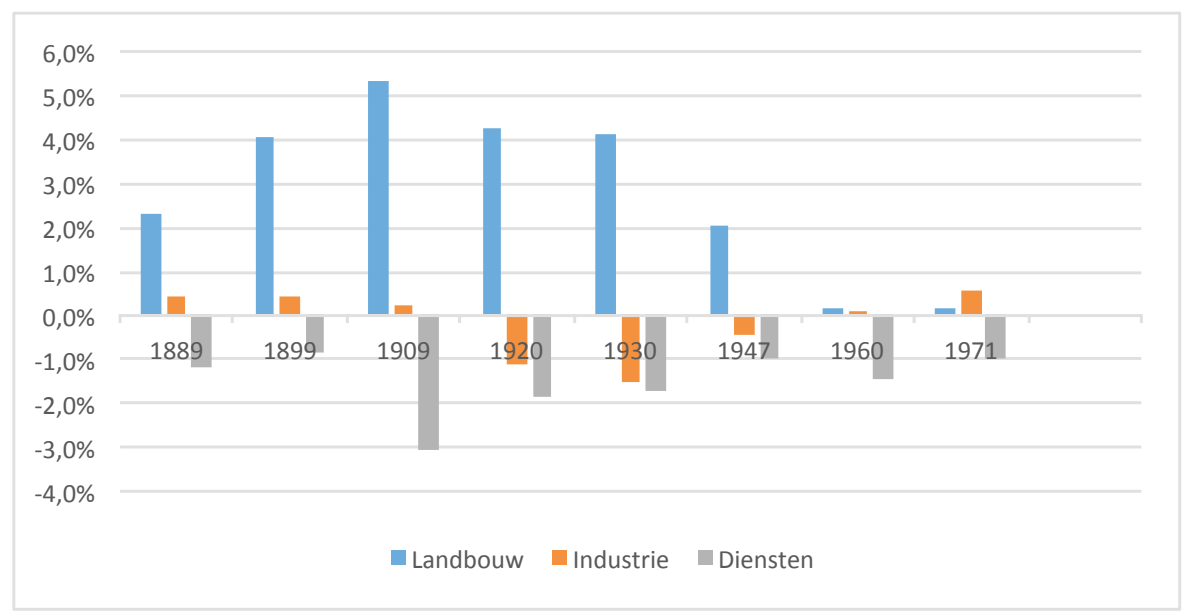

NB 'Vrouwelijke arbeidsparticipatie' gedefinieerd als het aantal vrouwen met een geteld beroep ten opzichte van de totale vrouwelijke bevolking.

Bronnen: Beroepstellingen 1889-1971. 


\section{Het debat over het mannelijke kostwinnersmodel}

In de sociaaleconomische geschiedenis van de vrouwenarbeid is het sinds het baanbrekende werk van Louise Tilly en Joan Scott, Women, Work, and Family uit 1978 gebruikelijk de arbeid door vrouwen in verband te brengen met de economische structuur van het gezin. ${ }^{8} \mathrm{Zij}$ maakten een onderscheid tussen de family economy, waarin echtparen en kinderen samenwerken, zoals in het boerengezinsbedrijf, de family wage economy, waarin gezinsleden ieder naar vermogen looninkomen inbrachten, en de family consumer economy, waarin het gezin alleen als consumptieeenheid verschijnt op basis van het inkomen van één kostwinner, in het algemeen de man. Dit laatste model staat ook bekend als de male breadwinner family, in het Nederlands het mannelijke kostwinnersgezin. Op deze indeling is veel kritiek gekomen, ${ }^{9}$ met name op de evolutionaire implicaties ervan, maar deze modellen geven als ideaaltypen wel inzicht in de relatie tussen de gezinssituatie en de vrouwenarbeid. De drie Limburgse voorbeelden die ik zojuist noemde representeren elk één van de drie typen: gezinsarbeid in de landbouw is een voorbeeld van de family economy, de loonarbeid van vrouwelijke gezinsleden in de Maastrichtse aardewerkindustrie van de family wage economy, en het strikte kostwinnersmodel in de gezinnen van mijnwerkers van de family consumer economy. Het feit dat deze drie economische gezinstypen in Limburg gedurende een groot deel van de twintigste eeuw tegelijkertijd voorkwamen, geeft aan dat deze classificatie niet zonder meer in een lineaire opeenvolging moet worden gezien, zoals Tilly en Scott impliceerden.

Uitgangspunt van deze indeling, en sindsdien standaard in elk debat over dit onderwerp, is dat het huishouden met één mannelijke kostwinner, dat tot niet zo lang geleden dominant was in de Westerse samenleving, een historisch verschijnsel is dat in de negentiende en twintigste eeuw is opgekomen, maar niet altijd heeft bestaan. In de jaren 1950 en 1960 kende het mannelijke kostwinnersgezin zijn grootste verbreiding, maar het lijkt nu weer te verdwijnen. Over het tempo en de oorzaken van de opkomst van het kostwinnersmodel wordt sinds de jaren 1990 een debat gevoerd dat tot veel onderzoek aanleiding heeft gegeven, ook in Nederland. ${ }^{10}$ Nederland is als casus interessant, omdat dit verschijnsel zich al vroeg voordeed en in de twintigste eeuw leidde tot een naar verhouding met andere landen

8 Louise A. Tilly en Joan W.Scott, Women, Work, and Family (New York 1978).

9 Zie onder meer Ad Knotter, 'Problems of the family economy: peasant economy, domestic production and labour markets in pre-industrial Europe', in: Maarten Prak (red.), Early Modern Capitalism. Economic and social change in Europe, 1400-1800 (Londen 2001) 135-160.

10 Een vroege samenvatting van dit debat geeft Angélique Janssens, 'The Rise and Decline of the Male Breadwinner Family? An Overview of the Debate', International Review of Social History 42 (1997), Supplement, 1-23. 
erg lage vrouwelijke arbeidsparticipatie. ${ }^{11}$ Voor de opkomst van het mannelijke kostwinnersgezin, en de afnemende participatie van vrouwen op de arbeidsmarkt als keerzijde daarvan, zijn algemene verklaringen gezocht in de stijging van de lonen van mannelijke arbeiders, die een bijdrage aan het gezinsinkomen van andere gezinsleden steeds minder nodig maakte, en in het doordringen van burgerlijke opvattingen over de plaats van de vrouw in het gezin in steeds meer lagen van de bevolking.

Het voorbeeld van de strikte arbeidsverdeling in de mijnwerkersgezinnen laat zien dat er een economische rationaliteit in het kostwinnersmodel stak, in die zin dat de concentratie van reproductieve en huishoudelijke taken bij vrouwen een continue intensieve en productieve inzet van mannelijke werknemers in de bedrijven mogelijk maakte. Daardoor konden weer hogere lonen worden uitbetaald, waarmee kon worden voorzien in het levensonderhoud van het hele arbeidersgezin en een bijdrage van vrouwen aan het gezinsinkomen, zoals in de family wage economy, overbodig werd. Dit verschijnsel past in het zogenoemde Fordistische bedrijfsmodel, dat volgens economisch-sociologen in de lange periode van hoogconjunctuur na de Tweede Wereldoorlog dominant werd in het Westerse kapitalisme: in navolging van autofabrikant Ford werd industriële massaproductie met een hoge arbeidsproductiviteit gecombineerd met relatief hoge lonen. ${ }^{12} \mathrm{De}$ reproductie van de hoogproductieve mannelijke kostwinner vond plaats in het gezin door huishoudelijke arbeid van de vrouw. Het is daarom niet toevallig dat de grootste uitbreiding van het mannelijke kostwinnersgezin in de jaren 1950 en 1960 samenviel met het hoogtepunt van het Fordisme. Tegelijk werden aan huishoudelijke taken op het gebied van voeding, verzorging en opvoeding steeds meer eisen gesteld, waaraan de huisvrouw alleen door een volledige inzet kon voldoen.

Het toenemende belang van het mannelijke kostwinnersgezin ging gepaard met een terugtrekkende beweging van gehuwde vrouwen van de arbeidsmarkt, maar het is niet zo gemakkelijk om die te meten. Eén van indicatoren die daarvoor door onderzoekers zijn gebruikt, is het aantal bruiden dat bij de huwelijksregistratie in de burgerlijke stand een beroep vermeldde. ${ }^{13}$ Voor Nederland zijn die

11 Voor een kritisch overzicht Schmidt en Van Nederveen Meerkerk, 'Reconsidering The "First MaleBreadwinner Economy”. Zie ook de recente dissertatie van Corinne Boter, Dutch Divergence? Women's Work, Structural Change, and Household Living Standards in the Netherlands, 1830-1914 (Wageningen 2017).

12 Vgl. over het 'Fordisme' in relatie met het mannelijke kostwinnersmodel ook Colin Crouch, Social Change in Western Europe (Oxford 1999) 38, 201.

13 Onder meer door Frans W.A. van Poppel, Hendrik P.van Dalen en Evelien Walhout, 'Diffusion of a Social Norm: Tracing the Emergence of the Housewife in the Netherlands, 1812-1922', The Economic History Review. New Series 62 (2009) 99-127; Wiebke Schulz, Ineke Maas en Marco H.D. van Leeuwen, 'When women disappear from the labour market: occupational status of Dutch women at marriage in a modernizing society, 1865-1922', The History of the Family 19 (2014) 426-446; Boter, Dutch Divergence?, 45-66. 
gegevens digitaal beschikbaar dankzij de door de rijksarchieven opgebouwde database 'WieWasWie'. Het probleem van deze bron is dat de registratie van beroepen van huwende vrouwen niet alleen de feitelijke beroepsuitoefening weerspiegelt, maar evenzeer de sociale norm of die wel wenselijk is. Ook al werkten vrouwen bij of vlak vóór hun huwelijk, het veldwinnen van die norm kan in toenemende mate aanleiding zijn geweest geen beroep op te geven. De daling van het percentage vrouwen met een beroepsvermelding in de huwelijksakten in de tweede helft van de negentiende en de eerste decennia van de twintigste eeuw, die wij zien in grafiek 3, kan dus zowel een gevolg zijn van een feitelijke vermindering van de vrouwelijke arbeidsparticipatie als van de toenemende verspreiding van het idee dat een echtgenote primair huisvrouw zou moeten zijn.

Grafiek 3. Het percentage bruiden met beroepsvermelding in de huwelijksakten in Limburg en Nederland, 1812-1932

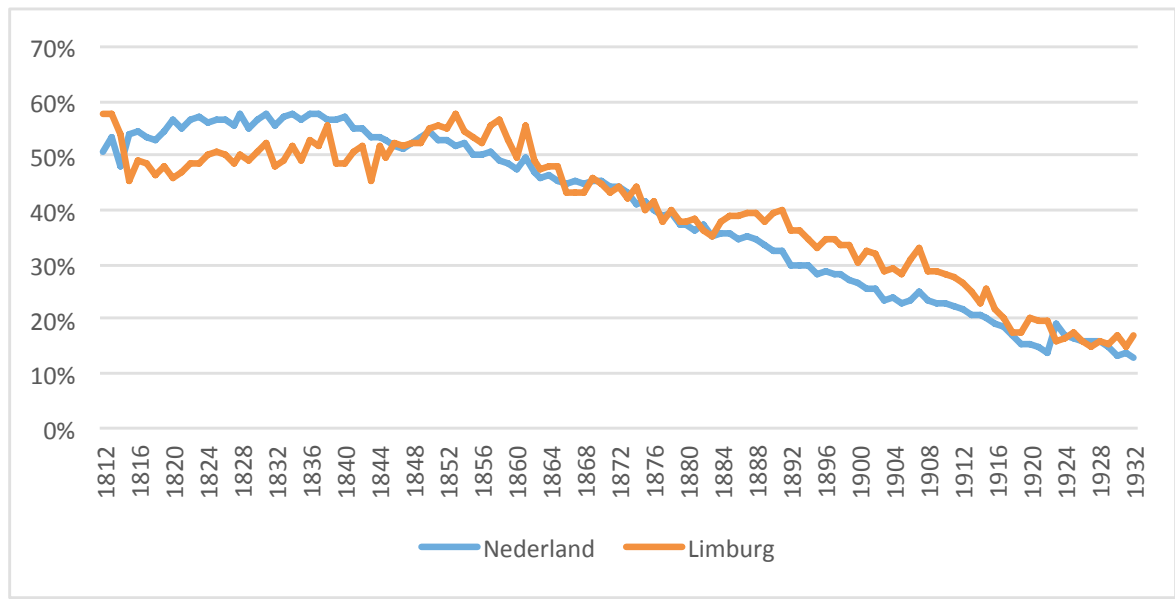

Bron: Database 'WieWasWaar', voor Nederland aan mij ter beschikking gesteld door Corinne Boter (Wageningen), voor Limburg door Simone Smeets (Regionaal Historisch Centrum Limburg).

Het aandeel van bruiden met registratie van een beroep in de huwelijksakten daalde in Limburg na omstreeks 1860 in hetzelfde ritme als in Nederland als geheel, namelijk van boven de 50 procent naar onder de 20 procent, maar lag in de periode tussen 1880 en 1920 in Limburg wel op een hoger niveau. Dit bevestigt het beeld 
van een grotere vrouwelijke arbeidsparticipatie in Limburg in die periode, die ook al bleek uit de beroepstellingen.

\section{Lokale en regionale verschillen}

Het is echter de vraag of dit lineaire verloop wel recht doet aan de grote verscheidenheid tussen bedrijfstakken en regio's. Dat geldt ook voor de gebruikelijke generieke verklaring voor de dalende vrouwelijke arbeidsparticipatie door de stijgende looninkomsten van de mannen, die het vrouwen mogelijk zou hebben gemaakt zich terug te trekken van de arbeidsmarkt. In haar recente Wageningse dissertatie uit 2017 stelt Corinne Boter dat deze verklaring aan de aanbodzijde moet worden aangevuld met verklaringen aan de vraagzijde, in het bijzonder de vraag naar arbeid van vrouwen op de lokale arbeidsmarkt. ${ }^{14}$ In de Limburgse mijnstreek, om dit voorbeeld weer aan te halen, bestond bijvoorbeeld nauwelijks vraag naar werk door vrouwen. Alleen mannen konden profiteren van de groeiende werkgelegenheid in het mijnbedrijf; voor hun vrouwen en dochters was daarin geen plaats. Vrouwen zochten wel mogelijkheden om door arbeid een inkomen te verwerven, maar die waren er eigenlijk alleen voor mijnwerkersdochters omdat de mijnbedrijven speciaal voor hen confectieateliers hadden opgericht. ${ }^{15}$ De eenzijdige arbeidsverdeling in het mijnwerkersgezin op basis van het mannelijke kostwinnersmodel werd dus mede bepaald door de structuur van de lokale arbeidsmarkt. Dit was natuurlijk heel anders in bedrijfstakken en locaties waar wel een grote vraag naar arbeid door vrouwen bestond, zoals in de Maastrichtse aardewerkindustrie of in de textielindustrie.

Belgische geografen hebben deze wat zij noemen 'uneven geography of gender relations' concreet onderzocht door een vergelijking te maken tussen het BelgischLimburgse mijnbouwgebied en de textielstad Gent. ${ }^{16}$ Door de verschillende economische structuur was er een groot contrast in vrouwelijke arbeidsparticipatie: in de jaren 1960 had 35 procent van de potentiële vrouwelijke beroepsbevolking in Gent betaald werk; in Belgisch-Limburg was dat slechts 18 procent. Door de traditionele arbeidsverdeling tussen mannen en vrouwen in de textielindustrie was

14 Boter, Dutch Divergence?

15 Vgl. Rutten, 'Het thuisfront van de mijnwerker', 417-421.

16 Karen Stuyck e.a., 'A Geography of Gender Relations: Role Patterns in the Context of Different Regional Industrial Development', Regional Studies 42 (2008) 69-82. Voor vergelijkbaar onderzoek naar het effect van verschillende soorten industrieën (waaronder mijnbouw) op arbeid door vrouwen in Engeland zie Valerie Hall, Women at Work, 1860-1939. How Different Industries Shaped Women's Experiences (Woodbridge 2013). 
de keuze voor loonarbeid voor de Gentse vrouwen een vanzelfsprekendheid, ook na hun huwelijk. In de gezinnen leidde dat tot een evenwichtiger verdeling van het huishoudelijke werk. In de Belgisch-Limburgse mijncité's daarentegen waren vrouwen op allerlei manieren aan huis gebonden. Net als in Nederlands-Limburg was er in de ruime omtrek geen werk voor vrouwen voorhanden en waren hun inspanningen in het huishouden noodzakelijk om de zware arbeid van mannen in de mijn mogelijk te maken. Zowel door mannen als door vrouwen werd dit ook als een dwingende sociale norm ervaren.

Achter de algemene tendens van dalende vrouwelijke arbeidsparticipatie en de opkomst van het mannelijke kostwinnersmodel kunnen zich dus grote regionale en lokale verschillen voordoen. In het volgende zal blijken dat dat ook in Limburg het geval was. Om de naar verhouding hoge vrouwelijke arbeidsparticipatie in Limburg tot het midden van de vorige eeuw en de omslag daarna te verklaren, zal $\mathrm{ik}$ het onderzoek daarnaar toespitsen op een aantal geselecteerde subregio's met een eigen economische structuur. Als uitgangspunt neem ik de verhoudingen per gemeente in het begin van de twintigste eeuw, die ik kon onderzoeken op basis van de beroepstelling van 1909. Behalve door de beschikbaarheid van gegevens per gemeente in deze telling, is de keuze daarvoor mede ingegeven door de veronderstelde grotere betrouwbaarheid wat betreft de vrouwelijke arbeidsparticipatie in de landbouw in vergelijking met de negentiende-eeuwse tellingen, met name wat betreft de inzet van vrouwelijke gezinsleden in het gezinsbedrijf. ${ }^{17}$

\section{Arbeid van vrouwen in Limburg: het regionale patroon in 1909}

Om de regionale verschillen in vrouwelijke arbeidsparticipatie in Limburg in kaart te brengen heb ik de gegevens per gemeente in 1909 allereerst ingedeeld in economischgeografische gebieden volgens de standaard-indeling van het CBS uit 1961 (zie tabel 1 en kaart 1). ${ }^{18}$ Opvallend is de hoge arbeidsparticipatie van vrouwen (tussen de 25 en 27 procent) in de landbouwstreken in Midden-Limburg en het Heuvelland. Dit hoge

17 Vgl. J.L.van Zanden, De economische ontwikkeling van de Nederlandse landbouw in de negentiende eeuw 18001914 (Utrecht 1985) 68-69 en Engelen en Kalkman, 'Vrouwenarbeid en zijn demografische achtergronden', 306-308. Zie voor de onderregistratie van werkende vrouwen in de landbouw in de negentiende-eeuwse tellingen ook Elise van Nederveen Meerkerk en Richard Paping, 'Beyond the census. Reconstructing Dutch women's labour market participation in agriculture in the Netherlands, ca. 1830-1910', The History of the Family 19 (2014) 447-468.

18 Vgl. Ronald van der Bie, De economisch-geografische indelingen van het CBS, 1917-1960 (Den Haag/Heerlen 2009). De indeling van de Limburgse gemeenten in economisch-geografische gebieden is ontleend aan Serge Langeweg, Mijnbouw en arbeidsmarkt in Nederlands-Limburg. Herkomst, werving, mobiliteit en binding van mijnwerkers tussen 1900 en 1965 (Hilversum 2011) 286-287. 
Kaart 1. Het percentage vrouwen met beroep in de Limburgse economisch-geografische gebieden in 1909

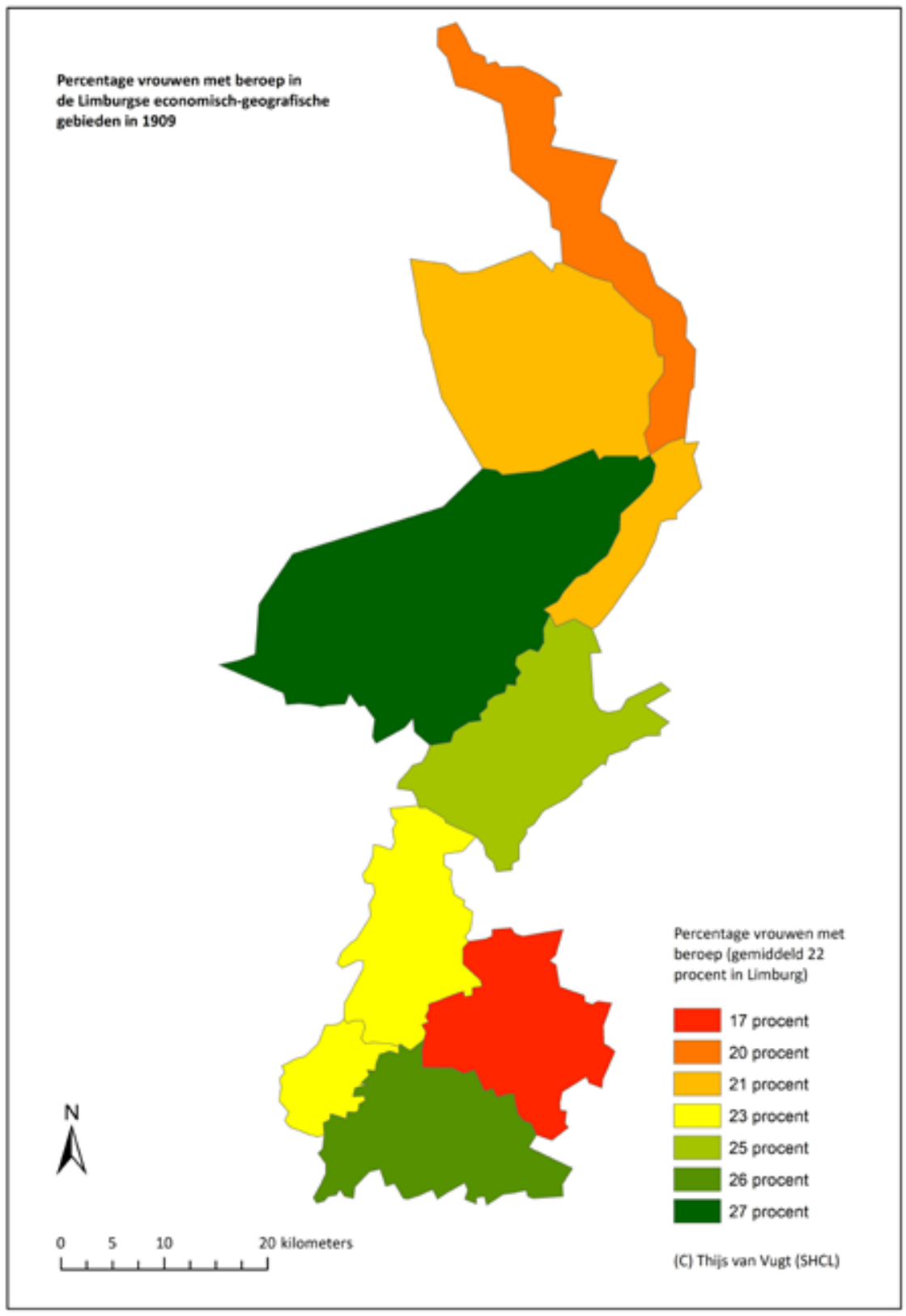


percentage is direct gerelateerd aan de arbeid van vrouwen in de landbouw. In het gebied ten westen van de Maas tussen Roermond en Weert was zelfs twee-derde van de vrouwen met een beroep in de landbouw werkzaam. Hoge percentages vrouwen in de landbouw vinden wij ook in het Heuvelland en in de latere Westelijke Mijnstreek. In 1909 was daar nog geen mijnbouw - die zou er pas komen na de opening van de mijn Maurits in Geleen in 1925. Daardoor was de landbouw daar in 1909 nog belangrijk en de vrouwelijke arbeidsparticipatie nog relatief hoog, namelijk 23 procent tegen 22 procent in de provincie als geheel. In de Oostelijke Mijnstreek, waar de mijnindustrie vanaf het begin van de eeuw sterk opkwam, is het aandeel van vrouwen met een beroep volgens verwachting wel een stuk lager dan het Limburgse gemiddelde (17 procent). Daar was ook het aandeel van vrouwen in de landbouw beperkt.

Tabel 1. Het percentage vrouwen met een beroepsvermelding en het aandeel van de landbouw in de vrouwelijke beroepsbevolking per economisch-geografisch gebied in Limburg, 1909

\begin{tabular}{|l|r|r|}
\hline Economisch-geografisch gebied & Percentage vrouwen met beroep & $\begin{array}{l}\text { Aandeel landbouw in vrouwelijke } \\
\text { beroepsbevolking }\end{array}$ \\
\hline Noord-Limburg & $20 \%$ & $47 \%$ \\
\hline Mook-Arcen en Velden & $21 \%$ & $47 \%$ \\
\hline Venray-Grubbenvorst & $21 \%$ & $10 \%$ \\
\hline Venlo-Beesel & & \\
\hline Midden-Limburg & $27 \%$ & $66 \%$ \\
\hline Maasbree-Weert-Thorn & $25 \%$ & $47 \%$ \\
\hline Swalmen-Roermond-Echt & & \\
\hline Zuid-Limburg & $23 \%$ & $58 \%$ \\
\hline Westelijke Mijnstreek & $17 \%$ & $34 \%$ \\
\hline Oostelijke Mijnstreek & $23 \%$ & $8 \%$ \\
\hline Maastricht en omgeving & $26 \%$ & $52 \%$ \\
\hline Heuvelland & $22 \%$ & $40 \%$ \\
\hline Limburg als geheel & & \\
\hline
\end{tabular}

NB 'Percentage vrouwen met beroep' gedefinieerd als het aantal vrouwen met een geteld beroep ten opzichte van de totale vrouwelijke bevolking.

Bron: Centraal Bureau voor de Statistiek, Uitkomsten der Beroepstelling in het Koninkrijk der Nederlanden gehouden op den een en dertigsten december 1909. Eerste deel. Overzicht voor iedere gemeente van Nederland van de voornaamste beroepen, die in de gemeente worden uitgeoefend [...] [Bijdragen tot de Statistiek van Nederland, Nieuwe Volgreeks No. CLXVII] ('s-Gravenhage 1912). 
Het belang van de landbouw in de vrouwelijke arbeidsparticipatie komt des te scherper naar voren als wij het aandeel van vrouwen met een geteld beroep in de totale vrouwelijke bevolking - dus inclusief kinderen en ouderen - in 1909 per gemeente bekijken. Op kaart 2 is te zien dat de hoogste percentages te vinden zijn in enkele landbouwdorpen in Midden-Limburg en Zuid-Limburg ten oosten van Maastricht. Uitschieters vinden we in Midden-Limburg ten westen van de Maas, met meer dan 40 procent in de plaatsen Haelen, Heel, en Wessem, en zelfs boven de 50 procent in Hunsel en Grathem (zie kaart 2). Het grote aandeel van de landbouw in de vrouwelijke arbeidsparticipatie in 1909 is in overeenstemming met het eerder geconstateerde gewicht van de landbouw in de vrouwelijke oververtegenwoordiging in de beroepsuitoefening in Limburg in het algemeen (zie grafiek 2). Het ten opzichte van Nederland als geheel wat hogere aandeel van vrouwen in de industrie in Limburg komt tot uiting in de wat hogere participatiegraad dan het Limburgse gemiddelde in Maastricht en omgeving, waar relatief veel vrouwen in de industrie werkten.

De uitkomsten van deze regionale vergelijking per economisch-geografisch gebied waren aanleiding in te zoomen op een aantal geselecteerde gemeenten binnen deze gebieden, die representatief kunnen worden geacht voor de arbeid door vrouwen - of het ontbreken daarvan - in de landbouw, de Maastrichtse industrie en de mijnbouw. Het betreft in de eerste plaats een tweetal clusters van landbouwdorpen met in 1909 de hoogste vrouwelijke arbeidsparticipatie in Midden-Limburg tussen Roermond en Weert en in het Heuvelland ten oosten van Maastricht. In de tweede plaats wordt ingezoomd op de stad Maastricht zelf, en in de derde plaats op de typische mijngemeenten in de Oostelijke en Westelijke Mijnstreken (zie tabel 2 en kaart 3). De keuze voor deze specifieke gemeenten doet de onder- en oververtegenwoordiging van vrouwen in de beroepsbevolking in 1909 des te scherper uitkomen. In de clustering komen de Midden-Limburgse landbouwdorpen ongeveer gelijk uit met die in het Heuvelland, namelijk respectievelijk 32 en 33 procent (tabel 2 en kaart 3), dat is 5 tot 6 procentpunten hoger dan in het omliggende economisch-geografische gebied. In deze clusters van dorpen met de hoogste vrouwelijke arbeidsparticipatie werkte ongeveer driekwart van de vrouwen in de landbouw.

De vrouwelijke arbeidsdeelname in alleen de stad Maastricht komt 3 procentpunt hoger uit dan in het economisch-geografische gebied inclusief de omliggende dorpen (26 tegen 23 procent), een bewijs dat die vooral werd bepaald door de vrouwenarbeid in de Maastrichtse industrie. Volgens de telling van 1909 waren er geen Maastrichtse vrouwen werkzaam in de landbouw. In de specifieke mijngemeenten werkten volgens verwachting relatief weinig vrouwen met een beroep. Opvallend is dat dat ook in de Westelijke Mijnstreek het geval was, hoewel daar toen nog geen 
Kaart 2. Het percentage vrouwen met beroep in de Limburgse gemeenten in 1909

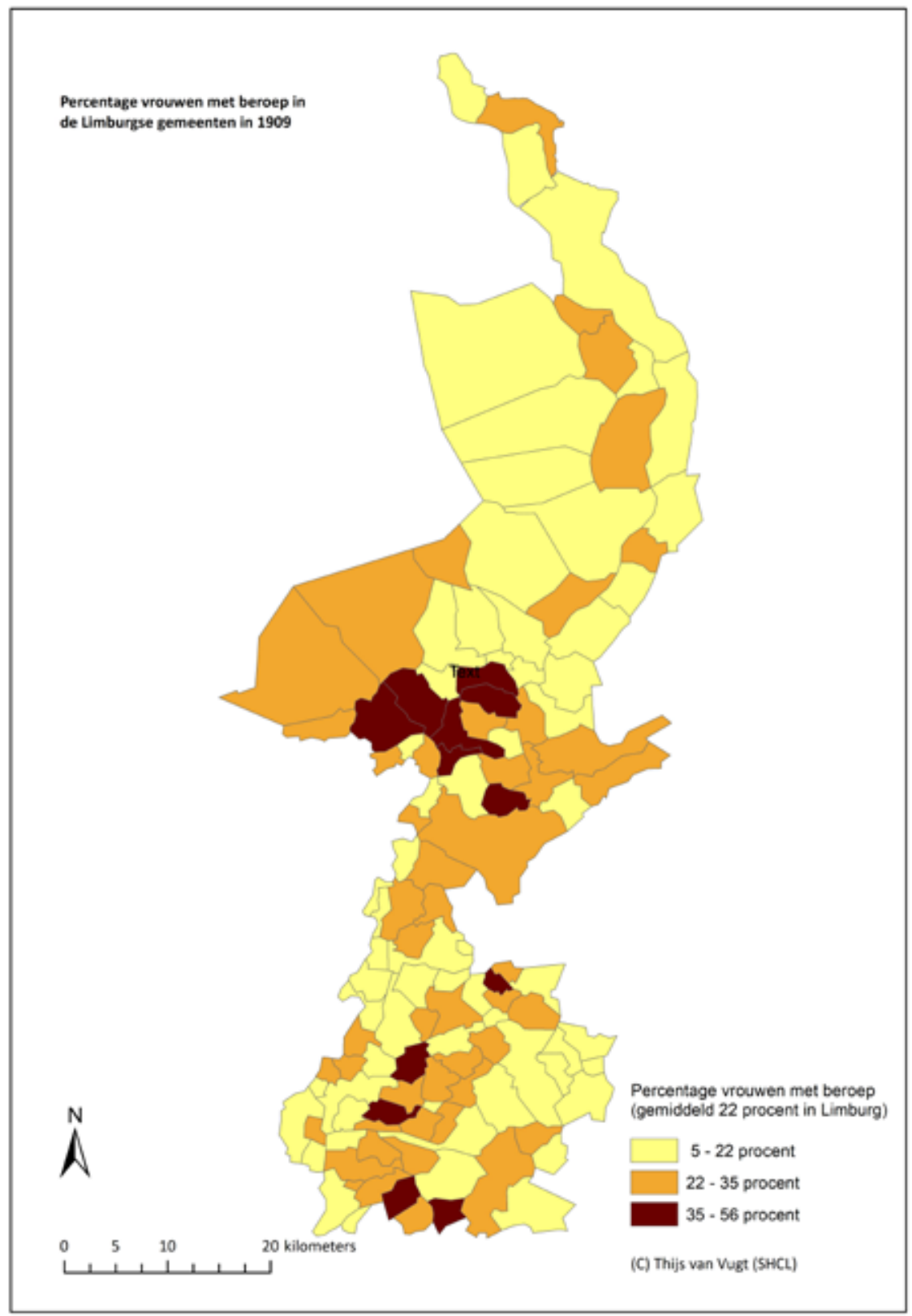


Kaart 3. Het percentage vrouwen met beroep in clusters van geselecteerde Limburgse gemeenten in 1909 (landbouwdorpen, mijngemeenten, Maastricht)

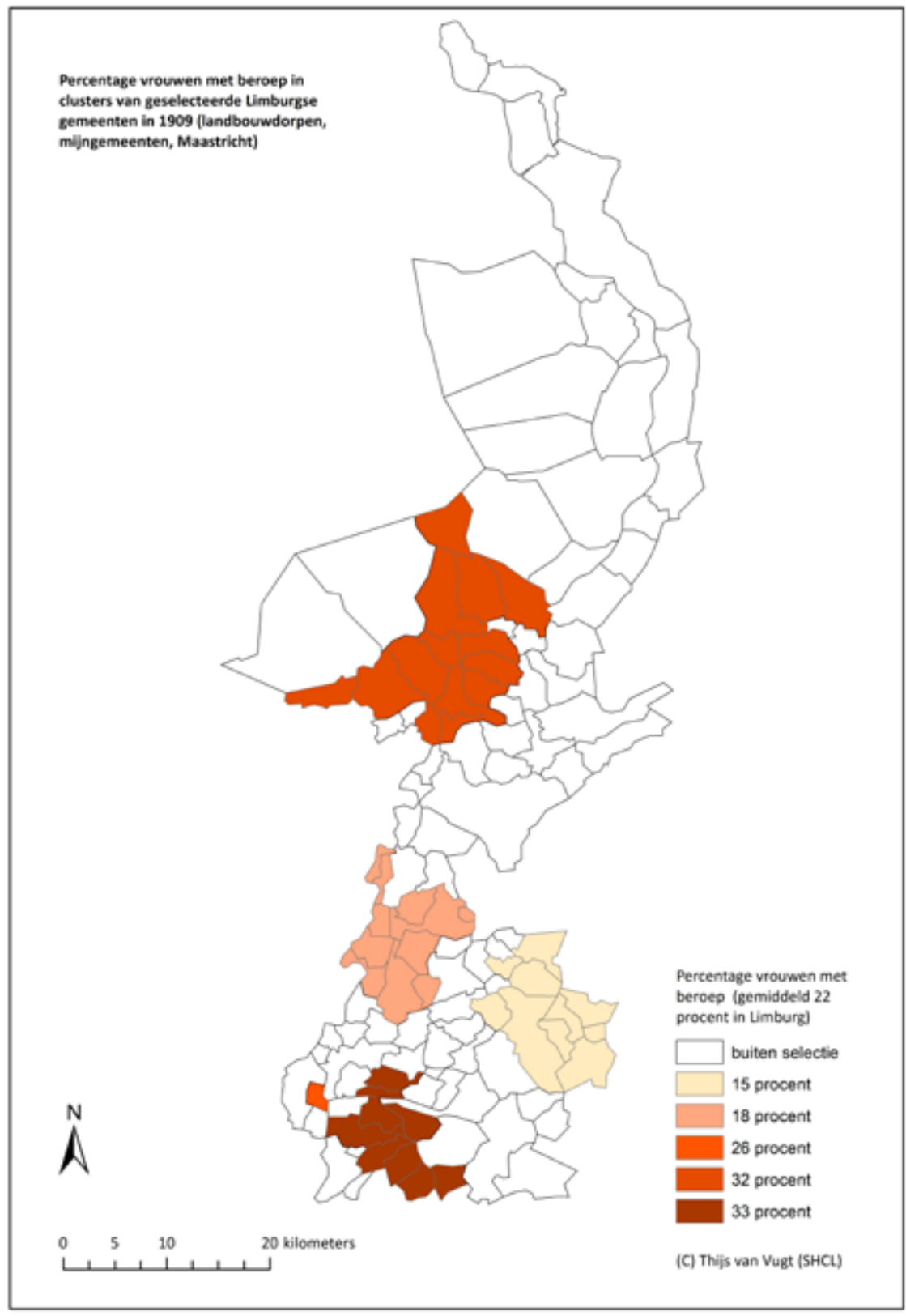


mijnen waren gevestigd. Wel was er in 1909 vanuit de dorpen in dit gebied een trek van boeren-mijnwerkers naar de mijnen in Heerlen op gang gekomen. Zij hielden vaak nog een boerenbedrijfje aan waarop vrouwen en kinderen werkzaamheden verrichtten. ${ }^{19}$ Dat verklaart mogelijk het hoge percentage vrouwen in de landbouw in deze gemeenten in de latere Westelijke Mijnstreek (44 procent).

Tabel 2. Het percentage vrouwen met een beroepsvermelding in clusters van landbouwdorpen in Midden-Limburg en het Heuvelland, in de mijngemeenten in de Oostelijke en Westelijke Mijnstreek, en in de stad Maastricht, 1909

\begin{tabular}{|l|r|r|}
\hline Geselecteerde gemeenten & $\begin{array}{l}\text { Percentage vrouwen } \\
\text { met beroep }\end{array}$ & $\begin{array}{l}\text { Aandeel landbouw in vrouwe- } \\
\text { lijke beroepsbevolking }\end{array}$ \\
\hline $\begin{array}{l}\text { Landbouwdorpen in Midden-Limburg ten } \\
\text { westen van de Maas* }\end{array}$ & $32 \%$ & $73 \%$ \\
\hline $\begin{array}{l}\text { Landbouwdorpen in het Heuvelland ten oosten } \\
\text { van Maastricht** }\end{array}$ & $26 \%$ & $76 \%$ \\
\hline Maastricht & $15 \%$ & $0 \%$ \\
\hline Mijngemeenten in de Oostelijke Mijnstreek† & $18 \%$ & $24 \%$ \\
\hline Mijngemeenten in de Westelijke Mijnstreek $\dagger \dagger$ & $22 \%$ & $44 \%$ \\
\hline Limburg & $40 \%$ \\
\hline
\end{tabular}

NB 'Percentage vrouwen met beroep' gedefinieerd als het aantal vrouwen met een geteld beroep ten opzichte van de totale vrouwelijke bevolking.

* Baexem, Grathem, Heythuysen, Hunsel, Meijel, Roggel, Stramproy, Beegden, Haelen, Heel en Panheel, Horn, Neer, Thorn, Wessem.

** Bemelen, Berg en Terblijt, Cadier en Keer, St.-Geertruid, Gronsveld, Margraten, Mheer, Noorbeek, Slenaken † Brunssum, Eygelshoven, Heerlen, Hoensbroek, Kerkrade, Merkelbeek, Nieuwenhagen, Schaesberg, Schinveld, Ubach over Worms

†† Beek, Elsloo, Geleen, Grevenbicht, Limbricht, Obbicht en Papenhoven, Sittard, Spaubeek, Stein, Urmond, Broeksittard Bron:zie tabel 1.

19 Vgl. Ad Knotter, 'The Miners of Geulle. Mining and Rural Transformation in Limburg (the Netherlands), 1900-1940', in: Paul Puschmann en Tim Riswick (red.), Building Bridges. Scholars, History and Historical Demography. A Festschrift in honor of Professor Theo Engelen (Nijmegen 2018) 285-310. 


\section{Vrouwen en arbeid per sector en regio, 1909-1971: mijnbouw, landbouw, Maastricht}

Om de ontwikkeling van de vrouwelijke arbeidsparticipatie in Limburg in de loop van de twintigste eeuw nader te kunnen analyseren, heb ik de op basis van de telling van 1909 gevormde clusters van landbouwdorpen, mijngemeenten en de stad Maastricht ook aangehouden voor een berekening van het percentage vrouwen met een beroep in deze clusters in de beroepstellingen van 1930, 1947, 1960 en 1971 (zie bijlage 1). Om deze cijfers beter inzichtelijk te maken heb ik de percentages weergegeven in een grafische voorstelling van de ontwikkeling in elk van de drie categorieën, steeds in vergelijking met het Limburgse gemiddelde (grafieken 4-6).

Grafieken 4-6. Het percentage vrouwen met een beroep in de mijngemeenten in de Oostelijke en Westelijke Mijnstreken, in geselecteerde landbouwdorpen in Midden-Limburg en het Heuvelland, en in Maastricht, 1909-1971

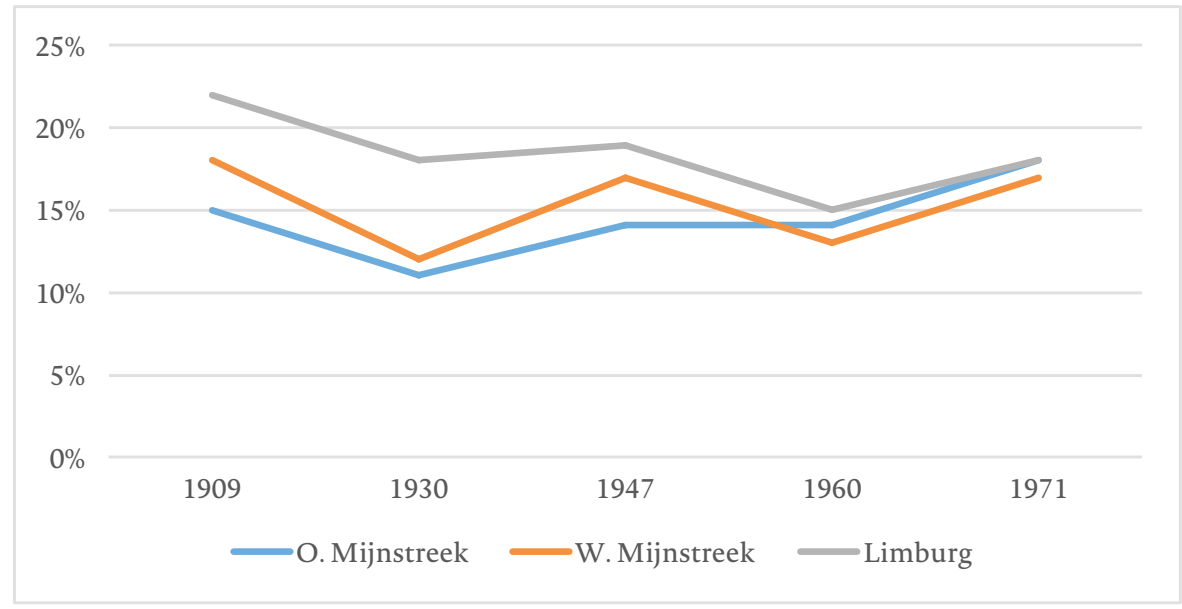



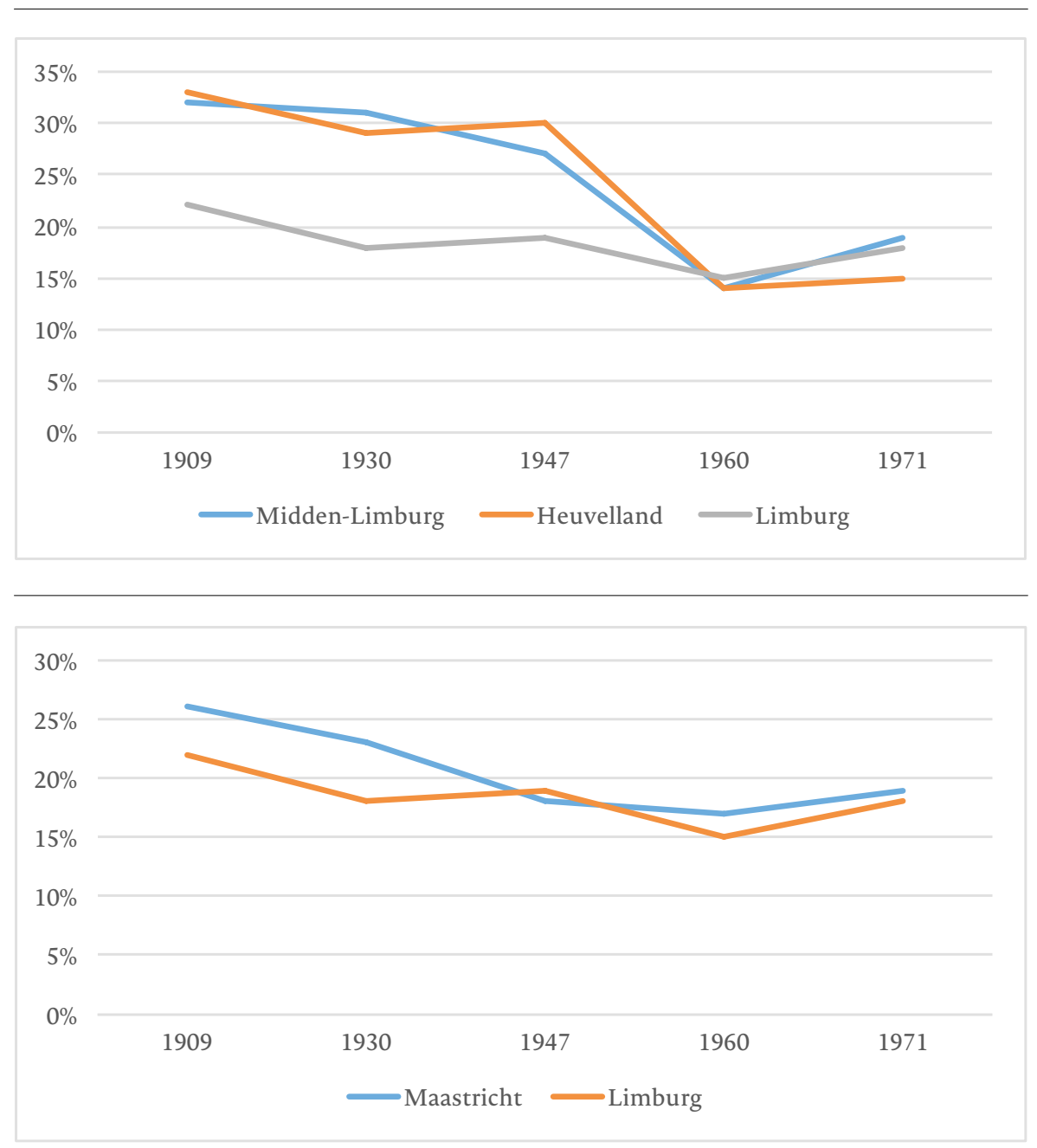

De ontwikkeling in elk van deze categorieën laat opmerkelijke verschillen zien. In de mijngemeenten lag de vrouwelijke arbeidsparticipatie gedurende de gehele periode onder het Limburgse gemiddelde, met een dieptepunt in 1930. Daarna nam die ook in verhouding tot Limburg als geheel weer wat toe om in 1971 uit te komen op ongeveer hetzelfde niveau als het Limburgse gemiddelde. In de landbouwdorpen bleef de vrouwelijke arbeidsdeelneming gedurende de gehele eerste helft van de twintigste eeuw op een relatief hoog niveau (met een lichte daling). Pas in de jaren tussen de telling van 1947 en 1960 nam die in korte tijd substantieel af tot 
het niveau van het Limburgse gemiddelde. Uit de gegevens van deze beroepstellingen zou dus kunnen worden afgeleid dat er in de jaren 1950 in Limburg een ware omwenteling heeft plaatsgevonden in de agrarische arbeidsverdeling tussen mannen en vrouwen. In wat volgt zal echter blijken dat deze uitkomst in het licht van andere tellingen aanzienlijk moet worden genuanceerd. In Maastricht daalde het aandeel van werkende vrouwen van betrekkelijk hoog in 1909 tot onder het Limburgse gemiddelde in de telling van 1947. Hieronder zal ik deze ontwikkeling per bedrijfstak en regio nader onderzoeken.

\section{Beroepsarbeid van vrouwen in de mijngemeenten}

De opkomst van de mijnindustrie in de mijngemeenten was in 1930 min of meer voltooid. In de Oostelijke Mijnstreek was er toen nog nauwelijks werkgelegenheid voor vrouwen in de landbouw. In de mijngemeenten in de Westelijke Mijnstreek was dat nog wel het geval: daar verdween die pas in de jaren 1950. Het grootste deel van de vrouwen in de mijnstreken werkte in de dienstensector, maar het aandeel daarvan nam wel af, vooral door de achteruitgang van het aandeel van dienstboden en andere huiselijke diensten in zowel de Oostelijke als de Westelijke Mijnstreek van respectievelijk 31 en 28 procent van de vrouwelijke beroepsbevolking in 1930 naar 9 en 10 procent in 1960. Met de groei van de bevolking in de mijngemeenten en van de koopkracht van de mijnwerkersgezinnen werd het werk van vrouwen in de dienstensector gevarieerder, onder meer door de toename van werk in de detailhandel, en dat gold ook voor de naar verhouding sterk groeiende vrouwelijke werkgelegenheid in de industrie. In 1930 was die in de mijngemeenten in de Oostelijke en Westelijke Mijnstreken nog grotendeels beperkt tot de kledingsector: daarin werkten toen respectievelijk 81 en 77 procent van de vrouwen in de nijverheid. In 1947 was dit percentage gedaald tot 58 en 52, en in 1960 tot 43 en 35 procent. ${ }^{20}$ Konden wij hiervoor in grafiek 4 vaststellen dat de vrouwelijke arbeidsparticipatie in de mijngemeenten na een dieptepunt in 1930 weer begon te groeien, en in tabel 3 dat het aandeel van vrouwen in de industrie naar verhouding het meeste toenam, dan lijkt er dus een zekere diversificatie van industriële werkgelegenheid voor vrouwen plaats te hebben gevonden die op dat punt positief uitwerkte. 
Tabel 3. De vrouwelijke beroepsbevolking naar sector in de mijngemeenten in de Oostelijke en Westelijke Mijnstreken, 1930-1960

\begin{tabular}{|c|c|c|c|c|}
\hline Mijngemeenten in de & Industrie & Landbouw & Diensten & $\mathbf{N}=$ \\
\hline \multicolumn{5}{|l|}{ Oostelijke Mijnstreek } \\
\hline 1930 & $14 \%$ & $5 \%$ & $81 \%$ & 7.525 \\
\hline 1947 & $27 \%$ & $5 \%$ & $68 \%$ & 11.649 \\
\hline 1960 & $31 \%$ & $0 \%$ & $69 \%$ & 14.313 \\
\hline \multicolumn{5}{|l|}{ Westelijke Mijnstreek } \\
\hline 1930 & $11 \%$ & $18 \%$ & $71 \%$ & 2.826 \\
\hline 1947 & $18 \%$ & $20 \%$ & $62 \%$ & 5.392 \\
\hline 1960 & $29 \%$ & $2 \%$ & $68 \%$ & 6.395 \\
\hline
\end{tabular}

Voor de selectie van mijngemeenten: zie tabel 2.

Bronnen:zie bijlage 1.

Dat neemt niet weg dat de kledingindustrie een belangrijk aandeel bleef houden in werkgelegenheid van met name mijnwerkersdochters. In de jaren 1930 nam Staatsmijnen het initiatief voor de oprichting van confectieateliers in Treebeek, Lutterade en Terwinselen, speciaal voor meisjes uit mijnwerkersgezinnen. Deze ateliers bleken in een grote behoefte te voorzien. Ook particuliere ondernemers vestigden tricotage- en confectiefabrieken in Zuid-Limburg. Na de oorlog breidde deze industrie zich verder uit: in 1966 waren er 33 confectiebedrijven in de mijnstreek gevestigd, waarin ongeveer 3.300 vrouwen en 1.100 mannen werkten. ${ }^{21}$ De industrie bood vooral werk aan jonge ongehuwde vrouwen uit mijnwerkersgezinnen. Dat weerspiegelt zich duidelijk in de leeftijdsopbouw van de vrouwen in de kledingsector in de mijngemeenten in de beroepstellingen van 1947 en 1971 (tabel 4). In 1947 was het percentage vrouwen in de kledingindustrie jonger dan 25 jaar in de mijngemeenten in de Oostelijke en Westelijke Mijnstreken respectievelijk 17 en 19 procentpunten hoger dan in de vrouwelijke beroepsbevolking als geheel. In 1971 waren deze verhoudingen in de Oostelijke Mijnstreek niet veranderd; in de Westelijke Mijnstreek was het aandeel van jonge vrouwen en meisjes zelfs nog toegenomen (tabel 4). 
Tabel 4. De leeftijdsopbouw van vrouwen werkzaam in de kledingsector in de mijngemeenten in de Oostelijke en Westelijke Mijnstreken, 1947 en 1971

\begin{tabular}{|c|c|c|c|c|c|c|}
\hline \multirow[t]{2}{*}{ Mijngemeenten in de } & \multicolumn{3}{|c|}{ Vrouwen in de kledingindustrie } & \multicolumn{3}{|c|}{ Vrouwelijke beroepsbevolking } \\
\hline & $t / m 24$ jaar & 25 jaar e.o. & $N=$ & $t / m 24$ jaar & 25 jaar e.o. & $\mathrm{N}=$ \\
\hline \multicolumn{7}{|l|}{1947} \\
\hline Oostelijke Mijnstreek & $74 \%$ & $26 \%$ & 2.004 & $57 \%$ & $43 \%$ & 11.887 \\
\hline Westelijke Mijnstreek & $67 \%$ & $33 \%$ & 510 & $48 \%$ & $33 \%$ & 5.471 \\
\hline \multicolumn{7}{|l|}{1971} \\
\hline Oostelijke Mijnstreek & $74 \%$ & $26 \%$ & 1.695 & $51 \%$ & $49 \%$ & 18.970 \\
\hline Westelijke Mijnstreek & $82 \%$ & $18 \%$ & 940 & $56 \%$ & $44 \%$ & 9.515 \\
\hline
\end{tabular}

Voor de selectie van mijngemeenten: zie tabel 2.

Bron:SHCL: Collectie CBS-statistieken, BH 1.1: Uitkomsten van de volks- en beroepstelling 31 mei 1947 per gemeente van de provincie Limburg; BH 1.3: 14 elgemene volkstelling annex woningtelling 28 februari 1971: definitieve uitkomsten per Limburgse gemeente.

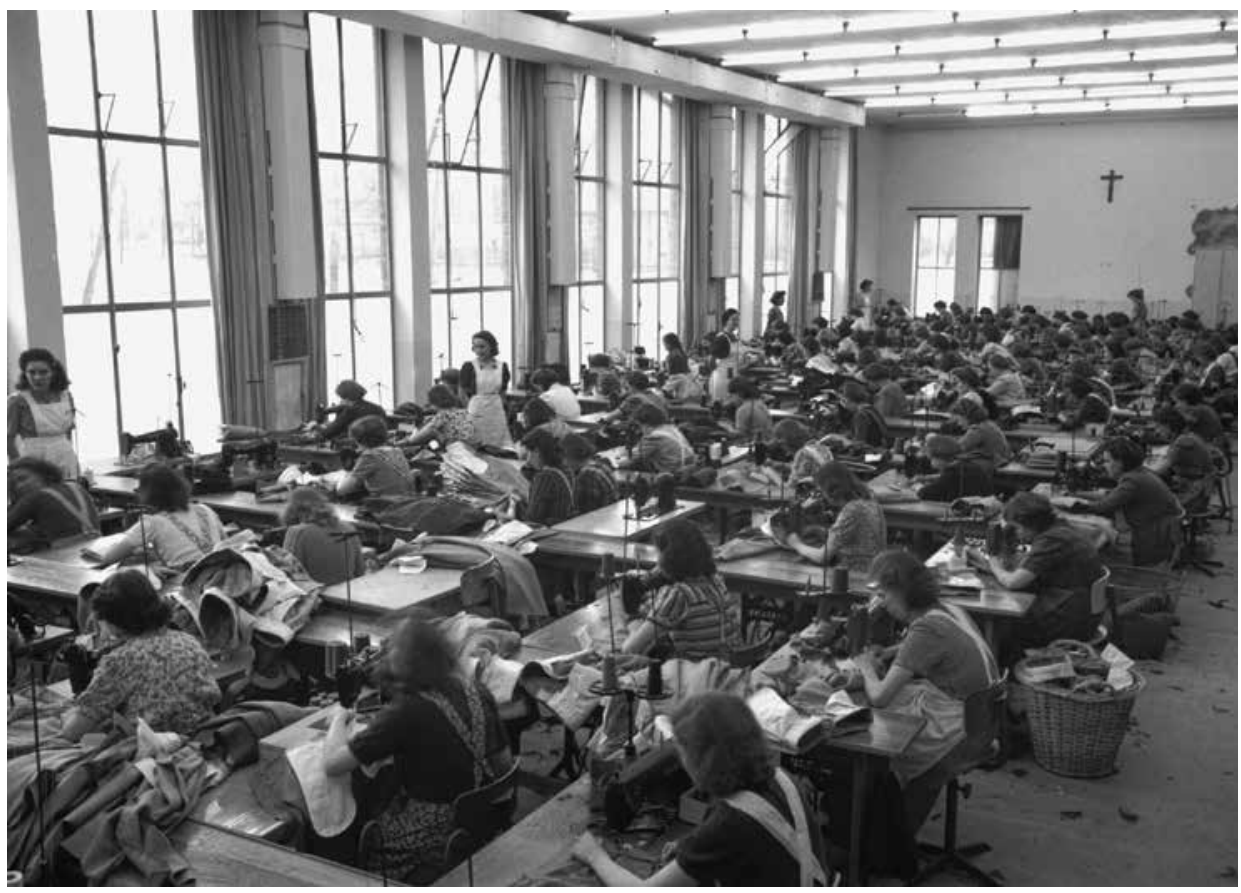

Afbeelding 2. De naaizaal van het confectieatelier Lindenheuvel, na 1 januari 1950 onderdeel van Chas Mackintosh, 1951. RHCL, fotocollectie Staatsmijnen/DSM. 
Onder deze jonge confectiewerksters vonden volgens een onderzoek van vlak vóór de Tweede Wereldoorlog 'abnormaal hooge personeelswisselingen' plaats, die 'ten nauwste samenhingen met de milieus waaruit de meisjes afkomstig zijn'.22 Verreweg de meeste kwamen uit mijnwerkersgezinnen en deze categorie 'treedt meestal vroegtijdig in het huwelijk en bovendien vormt haar loon slechts een betrekkelijk geringe en veelal niet noodzakelijke aanvulling van het gezinsinkomen. Vandaar dat er geen dwingende redenen voor deze vrouwen zijn om zeer lang in dienst te blijven'. De algemene tendens van een marginale arbeidsparticipatie van vrouwen in de mijnstreek werd dus door de vestiging van deze industrie niet opgeheven.

De werkgelegenheid voor vrouwen in de confectie-industrie in de mijnstreken bereikte een hoogtepunt tussen 1968 en 1971. In die jaren kreeg de industrie te kampen met onvervulbare tekorten op de arbeidsmarkt. Door de voorkeur voor meisjes en jonge vrouwen als arbeidskrachten kwam de personeelsvoorziening onder druk te staan. De langere opleidingsduur van jongeren in het algemeen en nieuwe arbeidskansen voor vrouwen in de opkomende dienstensector zorgden voor een afnemend aanbod in deze categorie. De concurrentie van lagelonenlanden leidde vanaf 1972 tot een neergang. Limburgse confectiebedrijven plaatsten daar steeds meer orders en vestigden er filialen. In de jaren 1970 en 1980 werd van jaar op jaar bericht over de inkrimping en sluiting van bedrijven, met een versnelling vanaf 1974. De werkgelegenheid in deze bedrijfstak kalfde daardoor steeds verder af. In 1985 werkten er in heel Limburg slechts 1.680 vrouwen in de kledingsector. In 1971 waren dat er nog 9.550 geweest. ${ }^{23}$

\section{Vrouwenarbeid in de landbouw}

In het gedenkboek bij het 25-jarig bestaan van de Limburgse Boerinnenbond in 1955 gaf auteur W.J. Vromen een overzicht van het werk van de boerin en haar dochters in - zoals hij het noemt - 'de oude tijd', zo'n 50 jaar eerder. ${ }^{24}$ Er was werk voor vrouwen in de veldarbeid, de veevoeding, de zuivelbereiding en de huishouding. Wat betreft de veldarbeid noemt hij de teelt, de oogst en het vervoer van veevoer, het wieden van onkruid, en hulp bij de graanoogst, met name het binden van de schoven. De zorg voor het vee, koeien, varkens en pluimvee, behoorde even-

22 J.J.J.van de Venne, 'De tricotage- en confectie-industrie in de mijnstreek', Economisch-Statistische Berichten 29 (1944) 64-68.

23 Ontleend aan Districtsbureau voor de Arbeidsvoorziening in de provincie Limburg, Arbeidsmarktbeschrijving van de Provincie Limburg 1968-1985 (Maastricht [1969-1986]). 
eens tot het domein van de vrouw, evenals de zuivelbereiding, zowel het melken als de boter-en kaasbereiding. De huishouding omvatte naast 'gewone' dagelijkse werkzaamheden zoals koken en schoonmaken, ook de teelt van groente en fruit voor eigen gebruik, inclusief het inmaken daarvan.

Interviews met in die tijd geboren boerinnen vertellen hetzelfde verhaal, zoals dat van een in 1908 geboren boerin uit Herten (bij Roermond):

Voordat ik zes jaar, was deed ik al werkjes op de boerderij. Met de koeien langs de weg zitten [...]. Het duurde een paar uur voordat ze volgegeten waren. [...] Melken en de stal leegmaken deden we vanaf dat we tien, twaalf jaar waren. Als je tien was, moest er 'duchtig' gewerkt worden. Overal aanpakken, op het veld, met het vee, hooien, aardappelen rapen, de 'hele smeer'. [...] We moesten mee naar het veld, schoven binden, met de zig maaien. ${ }^{25}$

Eenmaal getrouwd, moest zij het werk voor het bedrijf combineren met het werk in de huishouding. Ook dat laatste was arbeidsintensief, onder meer omdat de boerin zorg moest dragen voor de voedselvoorziening van haar gezin uit eigen stal en tuin. ${ }^{26}$

Landbouwenquêtes uit het eind van de negentiende en het begin van de twintigste eeuw bevestigen dat beeld. In het Onderzoek naar den toestand van den landbouw uit 1886 wordt over de Noord-Limburgse gemeente Meerlo meegedeeld: 'Vrouwen en kinderen werken mede, namelijk met wieden, binden van roggeschoven, poten en rooien van aardappelen, veevoeren, veehoeden, melken van het vee, karnen en boter bereiden'. ${ }^{27}$ In de Verslagen betreffende den Oeconomischen toestand der landarbeiders uit 1908 is over Limburg te lezen:

De voornaamste arbeid van vrouwen [...] bestaat in het werken in de boerderij, zooals de verzorging van het vee en verder huis- en stalwerk. Ook worden zij wel gebruikt voor het verrichten van gewoonlijk lichten veldarbeid als planten en oprapen van aardappelen, wieden van granen en wortelgewassen, hooien,

25 Geciteerd door Margit van der Steen, “'Ich bun altied un stjterk vroumus gewaes”. Leven en werken van een boerin in een Midden-Limburgse plattelandsgemeenschap, Herten 1910-1960', Studies over de sociaaleconomische geschiedenis van Limburg/Jaarboek van het Sociaal Historisch Centrum voor Limburg XLVII (2002) 137-155, aldaar 142.

26 Ibidem, 151-153; zie ook A. Gielen-Van Bommel, “Niks doen was er niet bij”. Het leven van een boerin en haar dochters in Horst aan het begin van deze eeuw', in: G.F. Verheijen e.a. (red.), Horster Historiën 3. Van boeren en ondernemers (Horst 1992) 203-226.

27 Uitkomsten van het onderzoek naar den toestand van den Landbouw in Nederland, ingesteld door de Landbouwcommissie, benoemd bij Koninklijk besluit van 18 September 1886, No.28. Derde Deel ('s-Gravenhage 1890) LXXXVIII, 11. 
schoven binden, bieten rooien, plukken van knolgewassen, spurrie en ander veevoeder. In de tuinbouwstreek worden door haar komkommers, boonen, erwten en andere groenten geplukt..$^{28}$

Enige jaren later (in 1912) werd in een onderzoeksrapport over de landbouw in Limburg gesteld: 'In die dagen stond de man te hoog om zich veel met de koeien te bemoeien, zulks werd aan de vrouwen overgelaten. Melken, en de mest uit den stal op de vaalt brengen, het was, en is nog wel, vrouwenwerk'. ${ }^{29}$ Maar in de jaren daarvóór was een deel van de vrouwelijke taken verlicht of afgestoten door 'de vrij algemeene invoering van de dorschmachine in het bedrijf, door de fabriekmatige zuivelbereiding en door de minder arbeid vorderende bemesting'. Daartegenover stond echter 'dat meer werk gevorderd wordt door de intensievere cultuur'. Van groot belang voor de inzet van vrouwelijke gezinsleden in het landbouwbedrijf was de groei en de toenemende intensiteit van de arbeid op het kleinbedrijf: 'Ontegenzeggelijk zijn de kleinere bedrijven in intensiteit het sterkst vooruitgegaan, vooral omdat het werk hier kan geschieden met eigen volk'. Op de kleine bedrijven op de zandgronden was 'de algemeene regel, dat baas, vrouw en kinderen allen gemeenschappelijk werken op de boerderij; de vrouw doet de keuken, maar ook niet zelden is ze belast met de werkzaamheden in den stal en enkele werkzaamheden op den akker' ${ }^{30}$ Over Zuid-Limburg wordt opgemerkt dat: '[...] de middelsoort boerderijen ten opzichte van de groote, vergelijkenderwijs in gunstiger conditie [zijn] gekomen, wijl deze in den regel grootendeels met eigen werkkrachten (vader, moeder, kinderen) kunnen worden geëxploiteerd' ${ }^{31}$

In heel Nederland was het volgens dit rapport 'een algemeen verschijnsel in de zandprovinciën, dat de uitkomsten van de kleine boerderijen, waar men in hoofdzaak werken kan met "eigen volk" [...] buitengewoon veel gunstiger geworden

28 Staatscommissie voor den landbouw ingesteld bij K.B. van 20 Juni 1906, No. 72, Verslagen betreffende den Oeconomischen toestand der landarbeiders in Nederland II: Utrecht-Limburg ('s-Gravenhage 1908) 361.

29 C. Bulden, 'Schets van de ontwikkeling van het landbouwbedrijf op de löss-gronden van Zuid-Limburg (ten Zuiden van Susteren)', in Staatscommissie voor den landbouw ingesteld bij K.B.van 20 Juni 1906, No. 72, Schetsen van het landbouwbedrijf in Nederland ('s-Gravenhage 1912) 345-356 aldaar 351. Nog in de jaren 1950 waren er 'onder de oudere generatie nog verscheidene boeren die òfwel in het geheel niet kunnen melken, òfwel dit pas op latere leeftijd hebben geleerd, terwijl er in Noord-Limburg [...] zelfs onder de [mannelijke AK] jongeren vooralsnog weinig animo bestaat om zich deze kunde eigen te maken aangezien de opvatting dat zulks toch eigenlijk door de vrouw behoort te worden gedaan, tot op heden min of meer voortleeft'. Ontleend aan C.D. Saal, Het boerengezin in Nederland. Sociologische grondslagen: gezin en bedrijf (Assen 1958) 203.

30 J.J.C.Ament, 'Schets van de ontwikkeling van het landbouwbedrijf op de zandgronden van NoordLimburg, het Land van Weert en het Peelland', in: ibidem, 449-464, aldaar 453 en 462-463.

31 Bulden, 'Schets van de ontwikkeling van het landbouwbedrijf op de löss-gronden van Zuid-Limburg', 354. 
zijn'. ${ }^{32}$ Daarvoor werden verschillende oorzaken aangegeven, waaronder de gestegen lonen van de landarbeiders, waardoor het werken met 'eigen volk' naar verhouding voordeliger werd. Het effect daarvan was in Limburg des te sterker, enerzijds omdat de landarbeiderslonen hier hoog waren door de zuigkracht van de Duitse arbeidsmarkt waar elk jaar duizenden Limburgers naar toe trokken als seizoenarbeiders, anderzijds omdat het aantal kleine bedrijven hier groter was dan vrijwel overal elders in Nederland. In Noord-Limburg had in 1912 omstreeks 70 procent van de boerderijen een omvang van 1 tot 5 hectare; een vergelijkbaar hoog percentage was er alleen in het Rijk van Nijmegen en op de Veluwe. In Noord-Limburg was bijna 90 procent kleiner dan 10 hectare; in Zuid-Limburg was dat met 86 procent van de bedrijven het geval. ${ }^{33}$ Dit grote aandeel van het kleinbedrijf, dat dreef op meewerkende gezinsleden, verklaart waarom het aantal in de landbouw werkende vrouwen in Limburg sinds het begin van de twintigste eeuw zo hoog was in vergelijking met Nederland als geheel. Nog in 1951 werd in een vergelijkend onderzoek naar het zogeheten kleine-boerenvraagstuk op de zandgronden in Nederland vastgesteld dat de meeste arbeid werd verricht door de vrouwen in de Limburgse dorpen. ${ }^{34}$

De in het gezinsbedrijf meewerkende boerinnen en boerendochters zijn apart geteld in de beroepstellingen van 1947 en 1960. In tabel 5 zijn die in percentages voor de geselecteerde landbouwdorpen per bedrijfshoofd weergegeven. Eerder bleek dat het aantal vrouwelijke arbeidskrachten in de landbouw volgens de beroepstelling van 1960 in de voorafgaande periode dramatisch zou zijn gedaald, nadat dit tot en met de telling van 1947 redelijk stabiel was gebleven. Uit tabel 5 kan worden afgeleid dat dit een gevolg was van een veel lagere telling van het aantal meewerkende vrouwelijke gezinsleden in 1960. Afgaande op deze telling zouden zij het werk op het boerengezinsbedrijf in het voorafgaande decennium massaal de rug hebben toegekeerd. Het aantal meewerkende boerinnen per mannelijk bedrijfshoofd zou tussen 1947 en 1960 zijn gedaald van 45 à 47 naar 4 à 5 procent; dat van boerendochters tot een vergelijkbaar laag percentage. ${ }^{35}$

32 Staatscommissie voor den landbouw ingesteld bij K.B. van 20 Juni 1906, No. 72, Overzicht van het landbouwbedrijf in Nederland ('s-Gravenhage 1912) 307.

33 Ibidem, 227 en 311.

34 A. Maris, C.D. Scheer en M.A. Visser, Het kleine-boerenvraagstuk op de zandgronden. Een economisch-sociografisch onderzoek van het Landbouw-Economisch Instituut (Assen 1951) 147.

35 In beide teljaren was de bijdrage van extern vrouwelijk personeel verwaarloosbaar klein. 


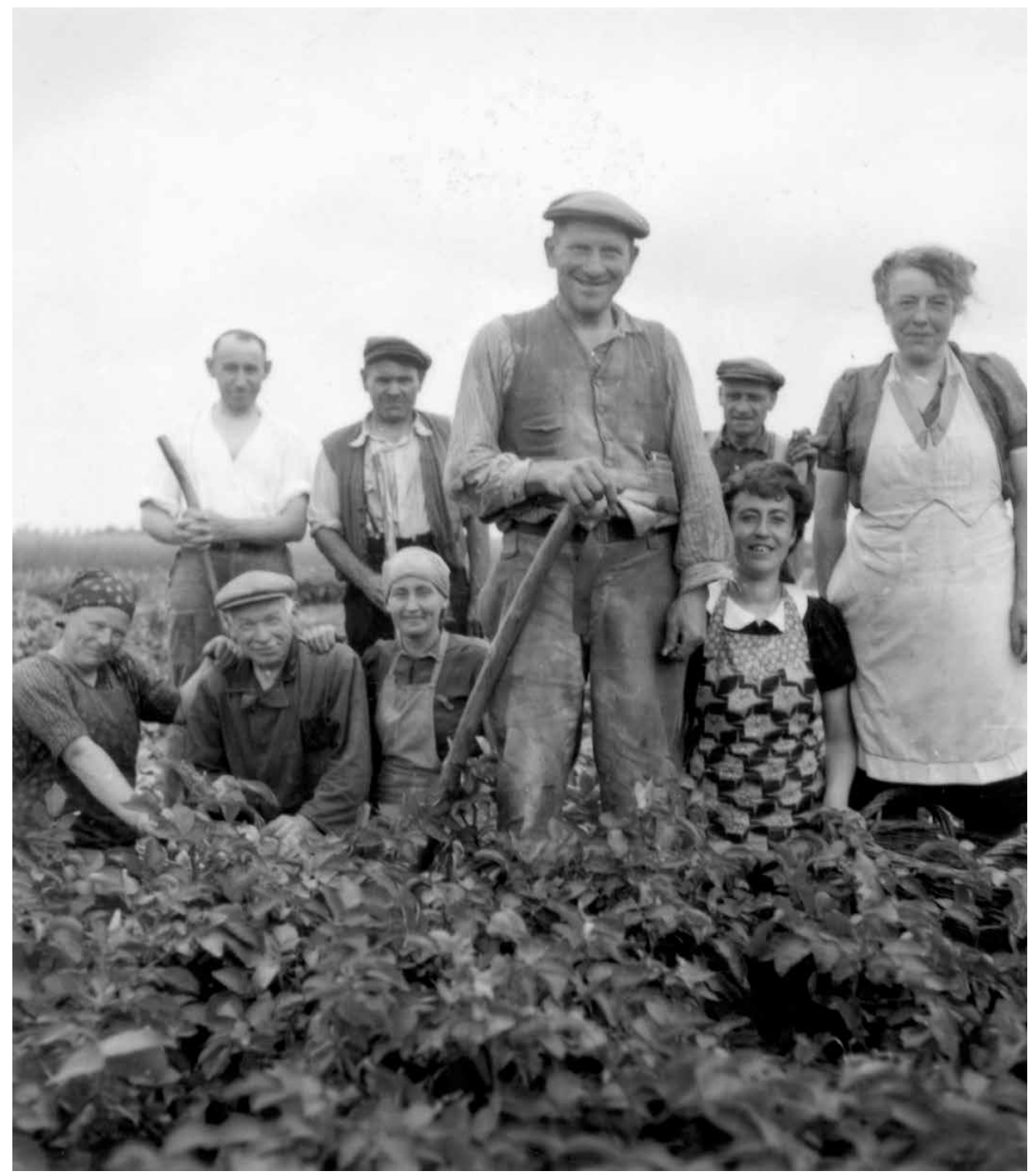

Afbeelding 3. Een Noord-Limburgse boerenfamilie poseert tijdens het werk voor de camera, omstreeks 1950.

Fotocollectie SHCL. 
Tabel 5. Het aantal meewerkende vrouwelijke gezinsleden en externe arbeidskrachten per agrarisch bedrijfshoofd in de geselecteerde landbouwdorpen in Midden-Limburg en het Heuvelland, 1947 en 1960

\begin{tabular}{|l|r|r|r|}
\hline Landbouwdorpen in & \multicolumn{2}{|l|}{ Meewerkende gezinsleden $(v)$} & Arbeidsters** \\
\hline & Echtgenotes* & Dochters** & \\
\hline Midden Limburg & & & $47 \%$ \\
\hline 1947 & $5 \%$ & $12 \%$ & $5 \%$ \\
\hline 1960 & & & \\
\hline Heuvelland & $47 \%$ & $45 \%$ & $6 \%$ \\
\hline 1947 & $4 \%$ & $7 \%$ & $1 \%$ \\
\hline 1960 & & & \\
\hline
\end{tabular}

Voor de selectie van landbouwdorpen zie tabel 2.

* per mannelijk bedrijfshoofd

** per mannelijk en vrouwelijk bedrijfshoofd

Bronnen: zie bijlage 1.

De conclusie van de landbouwhistorici Jansen en Rutten op basis van deze tellingen dat de vrouwelijke leden van het Limburgse boerengezin 'zich ook op het platteland nu uitsluitend op hun gezinstaak gingen toeleggen' is echter voorbarig. ${ }^{36}$ Er zijn goede redenen om aan te nemen dat de beroepstelling van 1960 de omvang van de arbeidsparticipatie van vrouwelijke gezinsleden in de landbouw ernstig onderschat. Ik wees daar al op in mijn inleiding wat betreft de Noord-Limburgse plaats Horst. De belangrijkste reden is dat meewerkende gezinsleden die minder dan 15 uur werkten in de telling van 1960 niet met een beroep zijn opgenomen. Hetzelfde geldt voor de telling van 1971. In 1947 was dat wel het geval. ${ }^{37}$ Er zijn zelfs aanwijzingen dat hun arbeid in de telling van 1947 zeer ruim is geïnterpreteerd en dat ook semi-huishoudelijk werk als agrarisch beroep is geteld. ${ }^{38}$ Daarentegen werd de agrarische arbeid van vrouwen op de boerderij zo'n 25 jaar later

36 J.C.G.M. Jansen en W.J.M.J. Rutten, Geschiedenis van de landbouw in Limburg in de twintigste eeuw (Leeuwarden/Mechelen 1992) 396.

37 A.B. Berends en A.C. Boelmans-Kleinjan, Beroepsarbeid door vrouwen in Nederland [Monografieën Volkstelling 1971 7] ('s-Gravenhage 1979) 41; zie ook Centraal Bureau voor de Statistiek, 13 Algemene Volkstelling 31 mei 1960. Deel 10. Beroepsbevolking. A. Algemene inleiding ('s-Gravenhage 1967) 11;idem, $12^{e}$ Volkstelling annex woningtelling 31 mei 1947. Serie A. Rijks-en provinciale cijfers. Deel 2. Beroepstelling ('s-Gravenhage 1952) 11.

38 Saal, Het boerengezin, 138-139. 
niet altijd als zodanig herkend. Bij de arbeidskrachtentelling van 1973 bleek: 'Een niet gering aantal vrouwen die 35 uur of meer in het gezinsbedrijf van hun man meewerken hebben bij het begin van het vraaggesprek niet geantwoord dat zij de uitoefening van hun beroep als voornaamste bezigheid hadden, maar dat zij in de eigen huishouding werkzaam waren'. ${ }^{39}$ Zelf definieerden de vrouwen hun werk op de boerderij dus ook niet altijd als beroepsarbeid. Het is op grond van deze beperkte gegevens niet mogelijk om vast te stellen of zich na 1947 een wijziging in de perceptie en de waardering van de vrouwelijke bijdrage aan het boerengezinsbedrijf heeft voorgedaan, maar er blijkt wel uit dat het zowel voor tellers als getelden moeilijk was om in deze gezinsbedrijven een scherp onderscheid te maken tussen productieve en consumptieve gezinsfuncties, zoals het in de gezinssociologie wordt genoemd..$^{40}$

Het is evenwel mogelijk een beter beeld van het aandeel van vrouwen in het gezinsbedrijf te krijgen door gebruik te maken van de periodieke arbeidskrachtentellingen in de landbouw, die vanaf 1947 om de drie jaar werden gepubliceerd als onderdeel van de landbouwtellingen van het CBS. Zij staan volkomen los van de tienjaarlijkse beroepstellingen en hebben een heel andere grondslag. In tegenstelling tot de beroepstellingen van 1960 en 1971 zijn alle op de boerderij meewerkende vrouwen meegeteld, ongeacht de omvang van hun werkzaamheden, dus ook vrouwen die minder dan 15 uur per week aan agrarische arbeid besteedden. Het verschil is zichtbaar in grafiek 7. De uitkomst van de beroepstelling van 1947 komt redelijk overeen met die van de arbeidskrachtentelling van dat jaar, maar in 1960 en 1971 is dat geenszins het geval. Gerekend naar het aantal werkzame personen (ongeacht het geschatte aantal arbeidsuren) is de daling van de vrouwelijke arbeidsparticipatie in de landbouw dus veel geleidelijker gegaan dan de vergelijking tussen de beroepstellingen van 1947 en 1960 suggereert. Pas in de jaren 1960 begon het aantal in het landbouwbedrijf werkende vrouwen substantieel te dalen.

Vanaf 1953 heeft men in de landbouwtellingen geprobeerd de agrarische bijdrage van de vrouwelijke gezinsleden in tijdseenheden te specificeren, maar het probleem van het diffuse onderscheid tussen huishoudelijke en agrarische arbeid in het boerengezinsbedrijf blijft ook in deze tellingen bestaan. ${ }^{41}$ Bovendien veran-

39 Berends en Boelmans-Kleinjan, Beroepsarbeid door vrouwen in Nederland, 14.

40 Saal, Het boerengezin, 130-132.

41 De landbouwtellingen 1950-1962 geven een omrekening van bestede arbeidsuren van vrouwen in 'arbeidsjaareenheden'. Van 1950 op 1953 zou de aldus berekende inzet van vrouwen in het landbouwbedrijf in Limburg plotseling zijn gedaald van 13.168 naar 7.599 arbeidsjaareenheden (en vervolgens naar 6.762 in 1956, 6.409 in 1959 en 5.622 in 1962); het aantal full time meewerkende boerinnen zou van 1953 op 1956 opeens zou zijn gedaald van 7.054 naar 1.425, dat is van 43 naar 8 procent van het totale aantal in de landbouw werkzame vrouwen in Limburg. In latere jaren komt dit uit op 12 à 13 procent. In beide gevallen rijzen twijfels over de gehanteerde telcriteria. 
Grafiek 7. Het aantal vrouwen werkzaam in de landbouw in Limburg volgens de beroepstellingen $(1947,1960,1971)$ en volgens de landbouwtellingen (1947-1983)

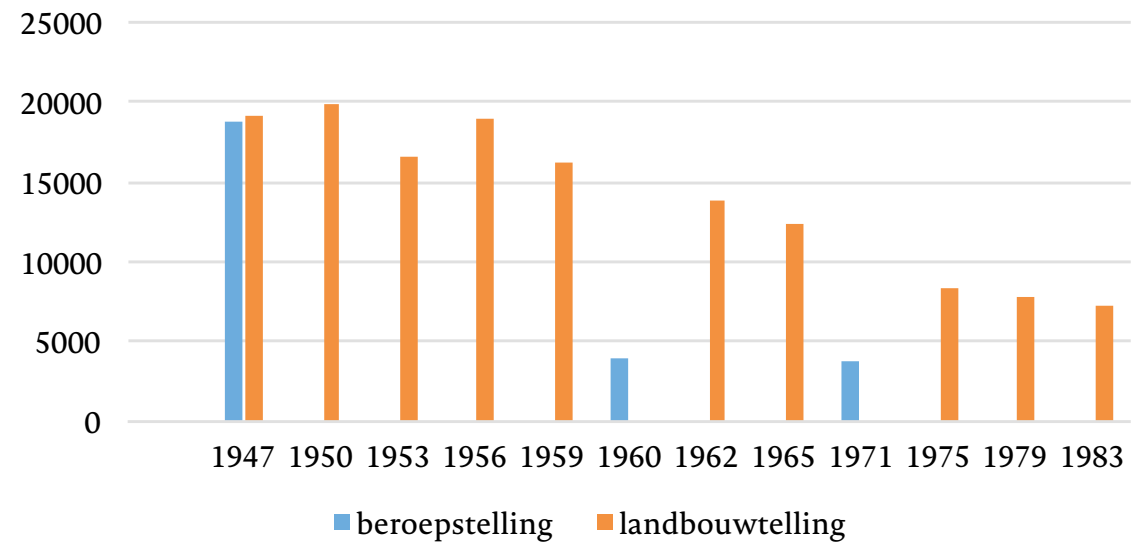

Bronnen: Beroepstellingen 1947, 1960,1971; CBS, Arbeidskrachten in hoofdzaak voor land- en tuinbouwwerkzaamheden 1947 [Bijzondere statistische opgaven Augustus 1948, no. 8004] (z.p. 1948); CBS, Landbouwtelling 1950 (Utrecht 1952); CBS, Statistiek arbeidskrachten in de land- en tuinbouw December 1956 (Zeist 1958); CBS, Landbouwtelling 1960 Deel 2 (Zeist 1963); CBS, Statistiek arbeidskrachten voor land- en tuinbouwwerkzaamheden 1962 (Zeist 1964); CBS, Statistiek arbeidskrachten voor land-en tuinbouwwerkzaamheden 1965 (s-Gravenhage 1967); CBS, Landbouwtelling 1975 deel 2: arbeidskrachten voor land-en tuinbouwwerkzaamheden (s-Gravenhage 1978); CBS, Landbouwtelling 1979 deel 2: arbeidskrachten voor land-en tuinbouwwerkzaamheden (s-Gravenhage 1981); CBS, Landbouwtelling 1983 deel 2: arbeidskrachten voor land-en tuinbouwwerkzaamheden ('s-Gravenhage 1984).

dert de indeling in bestede arbeidstijd nogal eens, zodat het ook om die reden niet goed mogelijk is vergelijkingen in de tijd te maken. Wel blijkt wellicht ten overvloede uit deze tellingen dat het steeds gaat om arbeid van meewerkende gezinsleden (tabel 6). In 1947 betrof dit 91 procent van de vrouwelijke arbeidskrachten in de Limburgse landbouw, in 1975 was dit gestegen tot 96 procent. In het laatste jaar komt dit percentage overeen met dat voor Nederland als geheel, maar in 1947 was het aandeel van werkende vrouwelijke gezinsleden in Limburg nog een stuk hoger dan landelijk. Het maakt zichtbaar hoe in Nederland het boerengezinsbedrijf in de periode na de Tweede Wereldoorlog steeds meer de norm is geworden. In Limburg was dat al vanouds het geval. Bij een sterk dalend aantal vrouwelijke werknemers in de landbouw in absolute zin - in Limburg zelfs sterker dan in Nederland als geheel (zie tabel 6, de laatste kolom) - nam het aandeel van in de landbouw werkende 
vrouwen in Nederland in deze periode daardoor sterker toe dan in Limburg (tabel 7, laatste kolom). Limburg werd dus steeds minder afwijkend wat betreft de vrouwelijke arbeidsparticipatie in de boerengezinsbedrijven. Limburgs relatieve voorsprong op dit gebied nam daardoor af.

Tabel 6. Het percentage vrouwelijke gezinsarbeidskrachten in het totaal van de in de landbouw werkzame vrouwen in Limburg en Nederland, 1947 en 1975

\begin{tabular}{|l|rr|r|r|r|r|}
\hline & \multicolumn{1}{|l|}{1947} & $\mathrm{~N}=$ & 1975 & $\mathrm{~N}=$ & $1947=100$ \\
\hline Limburg & $91 \%$ & 20.386 & $96 \%$ & 8.753 & 43 \\
\hline Nederland & $80 \%$ & 130.823 & $97 \%$ & 91.169 & 70 \\
\hline
\end{tabular}

Bronnen:zie grafiek 7.

Tabel 7. Het percentage vrouwelijke arbeidskrachten in de totale beroepsbevolking in de landbouw (m+v) in Limburg en Nederland, 1947 en (1971) 1975

\begin{tabular}{|l|r|r|r|r|r|}
\hline & 1947 & $\mathrm{~N}=$ & 1975 & $\mathrm{~N}=$ & Toename (procentpunten) \\
\hline Limburg & $27 \%$ & 75.900 & $36 \%$ & 23.039 & $9 \%$ \\
\hline Nederland & $14 \%$ & 913.447 & $30 \%$ & 331.252 & $16 \%$ \\
\hline
\end{tabular}

Bronnen: zie grafiek 7.

Volgens een in 1965 verschenen rapport over de landbouw in Limburg werd er enerzijds door 'de toenemende mechanisatie en rationalisatie [...] tezamen met de veranderende houding ten opzichte van de vrouw [...] vergeleken met vroeger in steeds mindere mate een beroep op de vrouwelijke gezinsleden gedaan', maar was anderzijds in alle gebieden een groter aantal vrouwelijke gezinsleden volledig gaan meewerken'. ${ }^{42}$ Deze paradoxale ontwikkeling hing nauw samen met een andere belangrijke verschuiving die zich onder de oppervlakte van de daling van het aantal vrouwelijke arbeidskrachten voordeed, namelijk een sterke afname van

42 Commissie voor de Agrarische Belangen in Limburg, Agrarische Welvaartsstudie 1965 (Maastricht [1965]) 77 en 85 . 
de bijdrage van de boerendochters. Dit proces was al in de jaren 1950 aan de gang, getuige een onderzoek uit 1958 naar de beroepskeuze van boerenjongeren op de zandgronden van Noord-Brabant en Limburg. ${ }^{43} \mathrm{Op}$ basis van interviews wordt in verschillende bewoordingen verslag gedaan van de afkeer van boerendochters van het werk op de boerderij. Ik citeer een aantal treffende uitspraken:

Bij de meisjes bestaat een tegenzin om boerin te worden. De moeders wakkeren dit soms aan.

De meisjes lopen in veel groter aantal uit de landbouw weg dan de jongens: $\mathrm{zij}$ hebben moeder en andere boerenvrouwen zo hard en lang zien werken, dat zij proberen het boerin worden te ontlopen.

De boerenmeisjes worden bij voorkeur geen boerin; zij hebben bezwaar tegen de lange werkdagen en zien op tegen het risico. ${ }^{44}$

Enzovoorts. Als alternatief gingen ze op zoek naar ander werk:

Van de boerenmeisjes hebben velen 'geen lust meer om haar leven lang slavin te zijn'. Daarom zoeken zij werk buitenshuis: de eenvoudigste als werkster; die iets meer kunnen worden gezinsverzorgster, verpleegster, kleuterleidster, onderwijzeres. Dochters van kleine boeren worden ook wel winkelmeisje; naar de fabriek gaat er geen. ${ }^{45}$

Deze boerendochters grepen hun kans om zich te ontplooien in de zich uitbreidende dienstensector. Trouwen met een boer werd daardoor voor hen steeds minder aantrekkelijk:

Een groot probleem is dat de meisjes geen boerin meer willen worden [...] Er zijn jonge boeren die zonder vrouw op een bedrijf zitten. ${ }^{46}$

Een actueel probleem, gezien het populaire TV-programma 'Boer zoekt vrouw', en ook de oplossing doet verrassend modern aan:

43 N.H.H.Addens, Over de beroepskeuze van boeren jongeren op de zandgronden van Noord-Brabant en Limburg ('s-Gravenhage 1959).

44 Ibidem, 70.

45 Ibidem, 73.

46 Ibidem, 74. 
De boer vindt het heel gewoon dat de vrouw in de stal en zelfs op het land helpt. Hij steekt echter geen hand uit om zijn vrouw eens in de huishouding te helpen, ook al is zij nog zo druk en zou hij er best tijd voor hebben. Dit moet veranderen. $^{47}$

Uit een uitsplitsing van de cijfers over de vrouwelijke gezinsarbeidskrachten naar de positie in het gezin op basis van de beroepstelling 1947 en de landbouwtellingen vanaf 1962 blijkt dat het aandeel van echtgenotes en vrouwelijke bedrijfshoofden in de gezinsarbeid op de boerderij in de jaren 1950 en 1960 inderdaad sterk toenam van 53 procent in 1947 naar ca. 97 procent in de jaren 1970 en 1980 (grafiek 8). De verdwijning van de boerendochters als arbeidskracht op de boerderij in deze periode kan zeker ook als onderdeel van de 'stille revolutie' in de vrouwelijke arbeidsparticipatie in Limburg worden beschouwd, met grote maatschappelijke consequenties. Zo heeft de historicus Paul Klep de afvloeiing van de meewerkende kinderen op de kleine boerenbedrijven in verband gebracht met de daling van de huwelijksvruchtbaarheid in de katholieke zuidelijke provincies in de jaren 1950 en $1960 .{ }^{48}$ Kinderen waren daardoor immers minder 'nuttig' voor de bedrijfsvoering. Onder verwijzing naar een onderzoek van de Katholieke Nederlandse Boeren- en Tuinders Bond over de 'relaties en de sfeer in het agrarische gezin' stelt hij vast dat het gezag van het boerengezinshoofd - de vader - door het uitvliegen van de kinderen afbrokkelde. Doordat vele kinderen, waaronder dus de dochters, nu hun toekomst buiten het gezinsbedrijf zochten, was de traditionele positie van de vader als bedrijfshoofd, werkgever en leermeester aanzienlijk verzwakt. Anders gezegd: het patriarchale karakter van de ouder-kindrelaties werd aangetast. ${ }^{49}$

In de jaren 1950 en 1960 werd het boerengezinsbedrijf en de positie van de vrouw daarin ook onderwerp van sociologisch onderzoek in Nederland, met name op de (toen nog) Landbouwhogeschool in Wageningen. ${ }^{50}$ Het boerengezin zou zich in een proces van modernisering bevinden, hetgeen onder meer tot uiting kwam

Ibidem, 75 .

48 Zie onder meer Paul Klep, 'Kleine boeren en grote gezinnen in crisistijd (1920-1970). Een nieuwe these', in: Jan Kok en Jan Van Bavel (red.), De Levenskracht der bevolking. Sociale en demografische kwesties in de Lage Landen tijdens het Interbellum (Leuven 2010) 141-196.

49 Ibidem, 151;idem, 'De Nederlandse katholieke boerenbonden en de agrarische gezinsproblematiek 1930-1962', Trajecta. Tijdschrift voor de geschiedenis van het katholiek leven in de Nederland [Moeizame moderniteit. Katholieke cultuur in transitie. Opstellen voor Jan Roes (1939-2003)] 13 (2004) 316-341, aldaar 328-333; KNBTB, De relaties en de sfeer in het agrarisch gezin ('s-Gravenhage 1961).

50 Vgl. Erwin H. Karel, 'Boer en gezin. De sociologisering van het boerenbestaan', in: idem, Boeren tussen markt en maatschappij. Essays over effecten van de modernisering van het boerenbestaan in Nederland (1945-2012) (Groningen/Wageningen 2013) 103-129. 
Grafiek 8. Het percentage vrouwelijke bedrijfshoofden en meewerkende echtgenotes in het totaal van de vrouwelijke gezinsarbeidskrachten in de landbouw in Limburg, 1947-1983

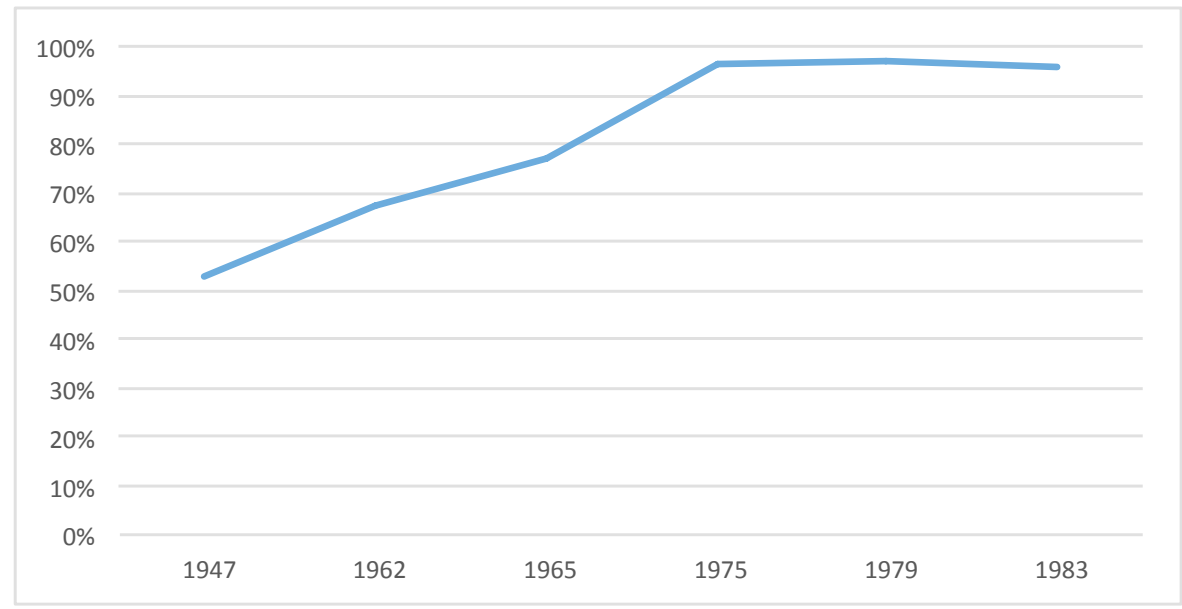

Bronnen: SHCL: Collectie CBS-statistieken, BH 1: Uitkomsten van de Volks-en Beroepstelling, 31 Mei 1947. Prov. Limburg; Landbouwtellingen 1962-1983 (zie grafiek 7).

in een toenemende scheiding tussen wat genoemd werd 'productieve' landbouwwerkzaamheden en 'consumptieve' gezinstaken. De boerin zou steeds meer uit het bedrijf verdwijnen om zich te concentreren op haar huishoudelijke werkzaamheden, ofwel haar 'essentiële gezinsfuncties', met als gevolg een 'niveauwinst van het gezin'. ${ }^{51}$ Deze 'functiereductie der vrouwelijke bedrijfstaak' zou volgens deze sociologen leiden tot de 'feminisering van de boerenvrouw', niet in de zin van 'emancipatie', want die was volgens deze sociologen gezien haar rol als bedrijfsgenote niet aan de orde, maar van 'een vrouwelijker-worden, meer nog: een nieuw existentiële beleving van haar vrouw zijn, met als symptomen een toenemende aandacht voor haar uiterlijk, voor lichaamsverzorging, kleding en haardracht'. ${ }^{52}$ Impliciet werd hiermee de bedrijfsarbeid door de boerin dus als 'onvrouwelijk' getypeerd. 
De sociologische moderniseringsthese over het boerengezin werd in de jaren 1950 en 1960 omgezet in beleid in de zogeheten huishoudelijke voorlichting ten plattelande, die vooral gericht was op de rol van de boerin als huisvrouw en gezinsverzorgster. Ook in Limburg was dit het geval. ${ }^{53}$ De relatieve stijging van het aandeel van vrouwen in de bedrijfsvoering bij een bijkans monopolie van meewerkende echtgenotes daarin (zoals bleek uit de tabellen 7 en 8), toont aan dat de boerinnen zich er weinig van hebben aangetrokken. Voor zover ik kan beoordelen hebben zij daarbij niet ingeboet aan 'vrouwelijkheid'.

\section{Vrouwenarbeid in de Maastrichtse glas-en aardewerk- industrie}

Fabrieksarbeid door vrouwen in de Maastrichtse industrie ging evenmin ten koste van de uiterlijke verzorging. Volgens de Rotterdamse feministe Marie RutgersHoitsema, die in 1906 een bezoek bracht aan Maastricht, zagen de vrouwen in de aardewerkfabrieken 'er voor het merendeel gezond, krachtig en opgewekt uit [...], vooral goed verzorgd en netjes in de kleren'. ${ }^{54}$ De glas- en aardewerkfabrieken verschaften veel werk aan Maastrichtse vrouwen zoals het overzicht in tabel 8 van de in 1909 getelde vrouwen met een beroep laat zien: de glas- en aardewerkfabrieken namen 83 procent van de fabrieksarbeid door vrouwen voor hun rekening. Daarnaast waren er vrouwen in de papier-, spijker en tabaksfabrieken, maar in aanzienlijk lagere aantallen. ${ }^{55}$ Omdat er ook veel vrouwen uit de omliggende dorpen in de Maastrichtse industrie werkten, was het aantal vrouwen in de fabrieken nog flink wat hoger dan de beroepstelling aangeeft. ${ }^{56}$ Die telde immers alleen de in Maastricht woonachtige beroepsbevolking. Volgens het in hetzelfde jaar gehouden onderzoek naar de fabrieksarbeid van gehuwde vrouwen in Nederland werkten

53 Vgl. Erwin H. Karel, 'Streekverbetering in Nederland en in Limburg, 1956-1970', Studies over de sociaaleconomische geschiedenis van Limburg/Jaarboek van het Sociaal Historisch Centrum voor Limburg LI (2006) 55-80, aldaar 74 .

54 M.W.H. Rutgers-Hoitsema, Arbeid van de gehuwde vrouw (Den Haag 1910) 18-19. Voor de context van haar bezoek zie Ad Knotter, 'Het Boschstraatkwartier in Maastricht in de eerste decennia van de twintigste eeuw. Een socialistisch (vrouwen)bolwerk', Stadsgeschiedenis 11 (2016) 24-48, aldaar 42.

55 Over de arbeid van vrouwen bij de Koninklijke Nederlandsche Papierfabriek (KNP) in Maastricht: Gertjan de Groot, Fabricage van verschillen. Mannenwerk, vrouwenwerk in de Nederlandse industrie (1850-1940) (Amsterdam 2001) hoofdstuk 8: 'Conducteurs en sorteerster: de Koninklijke Nederlandse Papierfabriek'; over de Maastrichtse spijkerfabriek: Eric van Royen, 150 jaar Thomas Regout N.V.: geschiedenis van een Maastrichts metaalverwerkend bedrijf,1834-1984 (Maastricht 1984).

56 Zie hierover ook Caspar Cillekens, 'Aardewerk en arbeidsmarkt: Maastricht tussen de twee wereldoorlogen', Studies over de sociaaleconomische geschiedenis van Limburg/Jaarboek van het Sociaal Historisch Centrum voor Limburg LII (2007) 115-135, aldaar 117-118. 
er 1.819 vrouwen in de Maastrichtse glas- en aardewerkfabrieken, dat is 334 meer dan volgens de beroepstelling, die dus volgens deze redenering in de omliggende gemeenten zouden hebben gewoond. ${ }^{57}$

Tabel 8. De samenstelling van de vrouwelijke beroepsbevolking in Maastricht naar beroepsgroep, 1909

\begin{tabular}{|c|c|c|c|}
\hline Bedrijfstak/beroepsgroep & aantal & \% in beroepsbevolking & \% in fabrieken \\
\hline \multicolumn{4}{|l|}{ Industrie } \\
\hline \multicolumn{4}{|l|}{ Fabrieksarbeidsters } \\
\hline - aardewerk, glas & 1.485 & & $83 \%$ \\
\hline -spijkers & 16 & & $1 \%$ \\
\hline - papier & 142 & & $8 \%$ \\
\hline - tabak en sigaren & 138 & & $8 \%$ \\
\hline Totaal fabrieksarbeidsters & 1.781 & $34 \%$ & $100 \%$ \\
\hline Fabr.van kleding/naaisters & 403 & & \\
\hline Totaal industrie & 2.184 & $41 \%$ & \\
\hline \multicolumn{4}{|l|}{ Diensten } \\
\hline Handel en verkeer & 508 & & \\
\hline Gezondheidszorg/onderwijs & 345 & & \\
\hline Huiselijke diensten & 1.547 & & \\
\hline Totaal diensten & 2.400 & $46 \%$ & \\
\hline Overige beroepen & 686 & $13 \%$ & \\
\hline Totaal vrouwelijke beroepsbevolking & 5.270 & $100 \%$ & \\
\hline
\end{tabular}

Bron: Beroepstelling 1909

Gezien het overwicht van de glas- en aardewerkindustrie in de werkgelegenheid voor vrouwen concentreer ik mij in het vervolg op deze bedrijfstak, en dan vooral op het bedrijf de Sphinx. Er waren meer aardewerkfabrieken in Maastricht, onder meer de Société Céramique en de Mosa, maar de Sphinx was de oudste en de grootste. Bovendien is het archief goed overgeleverd en ontsloten. De Sphinxfabrieken

57 Directie van den Arbeid, Onderzoek naar den Fabrieksarbeid van Gehuwde Vrouwen in Nederland ('s-Gravenhage 1911) 53. Het door Van Eijl, Het werkzame verschil, 45, noot 24 geconstateerde verschil in het aantal gehuwde vrouwen in de glas- en aardewerkfabrieken in Maastricht volgens dit onderzoek en de beroepstelling kan hiermee ook worden verklaard. 
waren in 1834 opgericht door de 'stamvader' van de fabrikantenfamilie Regout, Petrus I. Vanaf 1899 stond dit bedrijf bekend onder de naam 'de Sphinx'. Vooral na het midden van de negentiende eeuw nam het aantal arbeiders in zijn fabrieken sterk toe. Het grootste aantal werd in 1914 bereikt met ruim 3.700 werknemers. ${ }^{58}$

Grafiek 9. De omvang van het personeel van 'de Sphinx' (vóór 1899 Petrus Regout \& Co), onderverdeeld in vrouwen (gehuwd en ongehuwd) en totaal (mannen en vrouwen),(1849) 1974-1915 en 1925-1953

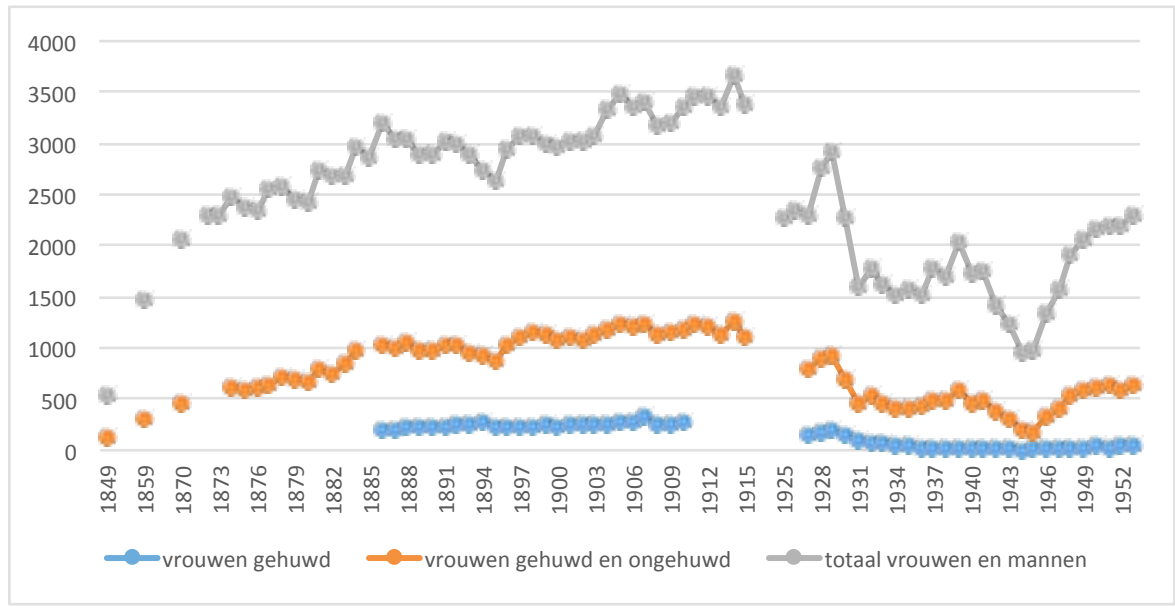

Bronnen: SHCL, archief Sphinx, EAN 1012, inv.nr.126, Contractenboeken 1848-1850, pp. 72-75: 'Staat van het personeel in de diverse Fabrijken van den Wel Edelen Heer P. Regout te Maastricht opgemaakt in Julij 1849'; inv.nr. 129, Contractenboeken 1857-1859, p. 132f:: 'Staat der werklieden welke op den 1 Januarij 1859 in de fabriek werkzaam zijn volgens eene nominatieve lijst'; inv.nr. 133, Contractenboeken 1867-1870, pp. 396-397: 'Staat aanwijzende het aantal Heeren Employés en werklieden gebezigd in de fabrijken van den Heer P. Regout op 1 Januarij 1870; inv.nr.723, Jaarverslagen van de Sociale Afdeling, 1926-1955; inv.nr. 823. Bevolkingsregister 1 Mei 1874-1 Mei 1885: 'Staat van opneming van het personeel in dit Register vermeld'; inv.nr. 830, 'Vergelijkende staten van aantallen mannelijke en vrouwelijke werknemers ...; inv.nr. 1768, 'Vergelijkende staten van verkoop, fabricatie enz.'; SHCL, archief Sphinx (aanvulling), EAN 1015, inv.nr. 8, 'Naamlijst van het Personeel van de Kristal-, Glas- en Aardewerkfabrieken “de Sphinx” voorheen Petrus Regout \& Co te Maastricht', 1900-1912: 'Staat van opneming van het personeel'. 
Grafiek 9 laat zien dat dit aantal in de rest van de twintigste eeuw niet meer werd gehaald. Gegevens over de periode van de Eerste Wereldoorlog en de eerste helft van de jaren 1920 ontbreken, maar er is voldoende informatie om in die jaren van een ernstige crisis in de glas- en aardewerkindustrie te spreken, met een grote werkloosheid onder de glas- en aardewerkers en -werksters als gevolg. In 1925 leidde de crisis tot het afstoten van de glasfabriek door Sphinx. Na een korte opleving in de late jaren 1920, stortte de werkgelegenheid in de jaren 1930 compleet in. ${ }^{59}$

Grafiek 10. Het aandeel van vrouwen in de totale fabrieksbevolking en het aandeel van gehuwde vrouwen in het totale aantal werkzame vrouwen bij Sphinx (vóor 1899 Petrus Regout \& Co) (percentages),(1849) 1974-1915 en 1925-1953

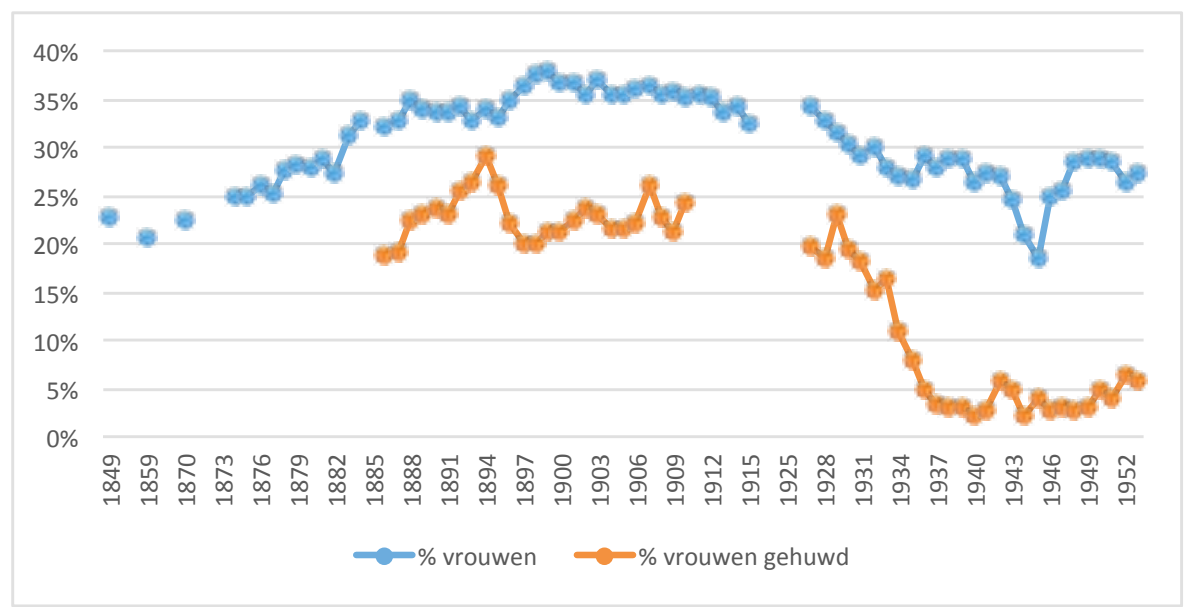

Bronnen: zie grafiek 9.

Om de groei van de fabrieken van Regout in de tweede helft van negentiende eeuw mogelijk te maken rekruteerde hij naar verhouding meer vrouwen dan mannen. Het percentage in zijn fabriek werkzame vrouwen groeide van 20 tot 25 procent in de jaren 1850 en 1860 naar 35 tot maximaal 38 procent in de jaren 1880 en 1890 (zie grafiek 10). In het begin van de twintigste eeuw bleef dit percentage ongeveer even hoog, en ook aan het eind van de jaren 1920 was het nog altijd 34 procent. Daarna zette een daling in. Afgezien van een abnormaal dieptepunt in de oorlogsjaren, 
varieerde het aandeel van vrouwen in de jaren 1930 en 1940 tussen de 26 en 29 procent. De daling van het aantal vrouwen vanaf 1930 deed zich onmiskenbaar ook voor in de beroepsbevolking in de Maastrichtse glas- en aardewerkindustrie als geheel - zowel in absolute als in relatieve zin (zie grafiek 11), en is dus niet specifiek voor het bedrijf 'de Sphinx'.

Grafiek 11. Mannen en vrouwen in de Maastrichtse glas- en aardewerkindustrie volgens de beroepstellingen 1859-1971

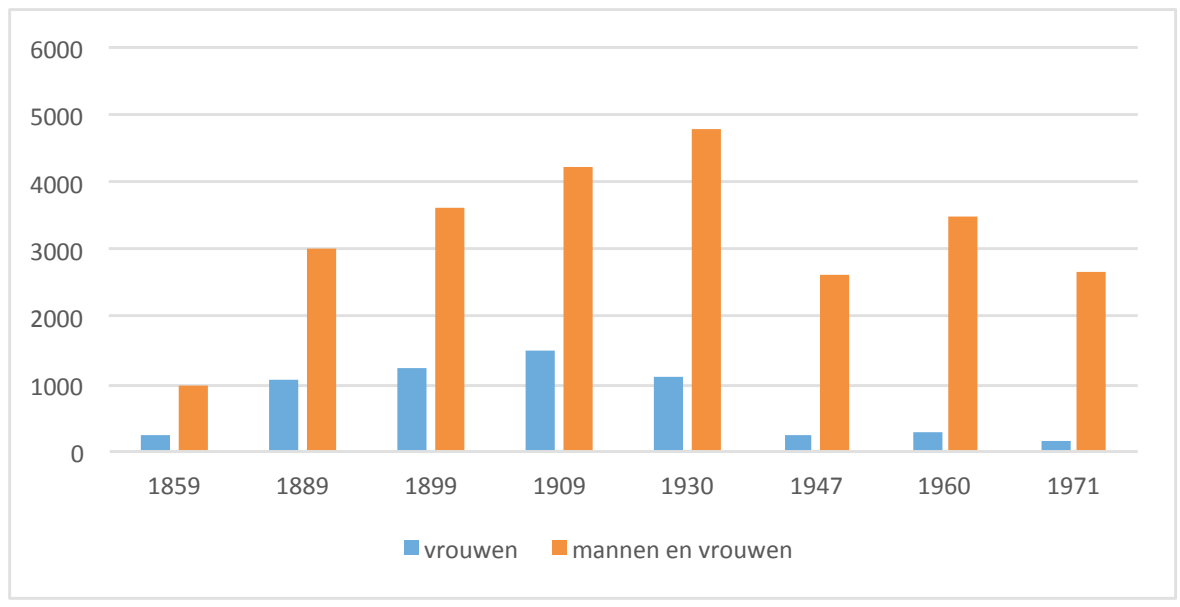

Bronnen: Beroepstellingen 1859-1971.

De relatieve groei van het aantal vrouwen in de Regout-fabrieken in de tweede helft van de negentiende eeuw was een gevolg van de sterke uitbreiding van de aardewerksector in zijn bedrijf. In zijn dissertatie over de seksesegregatie in de Nederlandse industrie in deze periode heeft Gertjan de Groot laten zien dat er bij Sphinx een vaste verdeling was in het werk tussen mannen en vrouwen. Die had Regout overgenomen van de Engelse bedrijven waarvan hij het productieproces had geimiteerd met behulp van speciaal geworven vakmensen. ${ }^{60}$ Vrouwen werkten voor het overgrote deel als ovenwerksters bij het vullen en leeghalen van de cassetten met te bakken en gebakken aardewerk en het aanreiken daarvan aan de mannelijke ovenwerkers; bij het schilderen, decoreren, bedrukken en vernissen van aardewerk;

60 De Groot, Fabricage van verschillen, hoofdstuk 7: 'Pielemannen en casettendraagsters: de aardewerkfabriek De Sphinx'. 
en bij het sorteren, inpakken en verzenden van de eindproducten in het magazijn. Naarmate de productie van aardewerk belangrijker werd ten opzichte van glas en kristal, moesten er voor deze taken relatief meer vrouwen worden geworven.

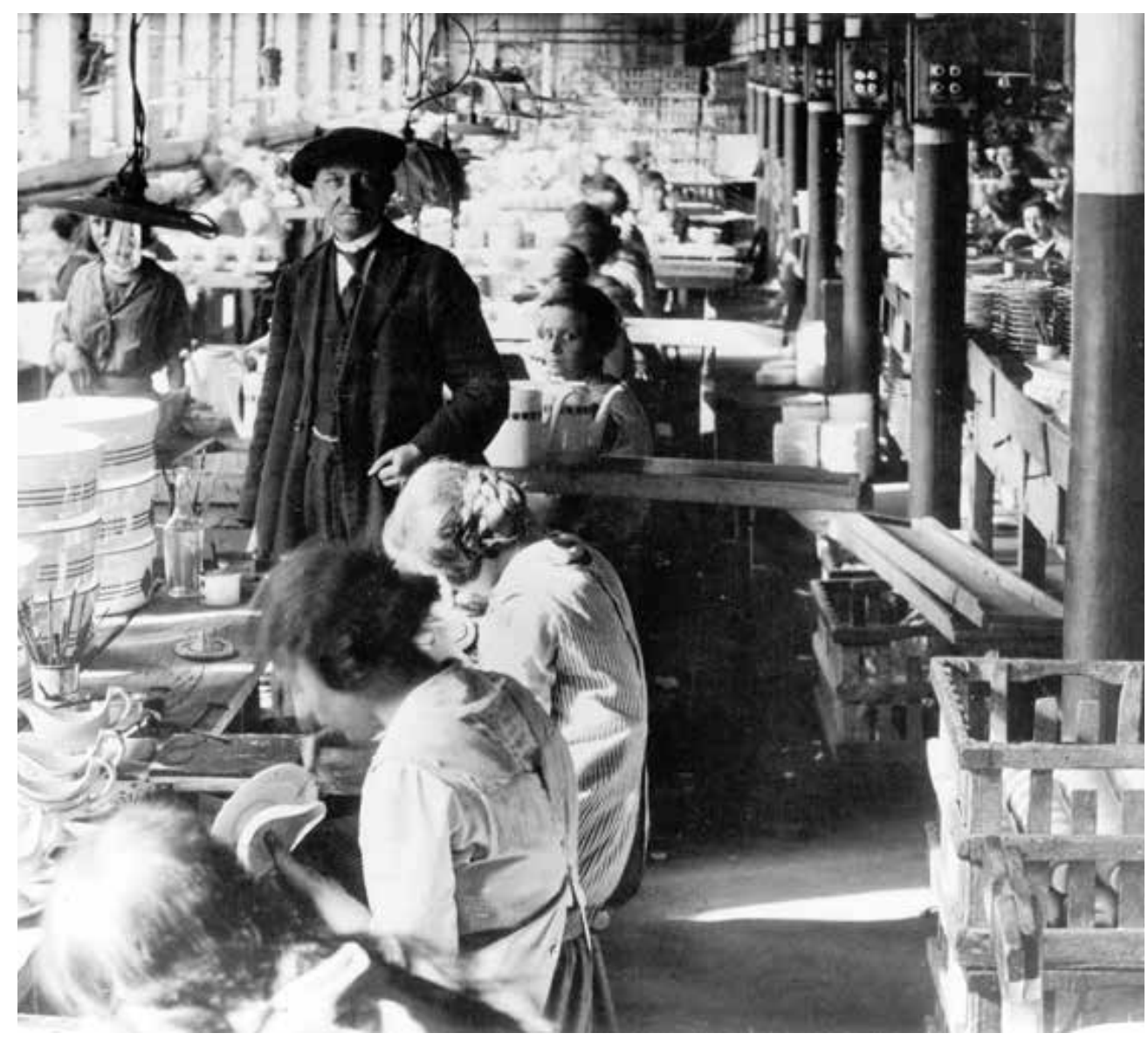

Afbeelding 4. Vrouwen aan het werk op de decoreerafdeling van Sphinx onder toezicht van een mannelijke opzichter, omstreeks 1930. Fotocollectie RHCL. 
Tabel 9. Het aantal mannen en vrouwen in de aardewerk- en sanitairafdelingen bij Sphinx, 1932 en 1948

\begin{tabular}{|l|r|r|r|r|r|r|r|r|}
\hline & \multicolumn{2}{|l|}{ Mannen } & \multicolumn{2}{l|}{ Vrouwen } & \multicolumn{2}{l|}{ Totaal } & \multicolumn{2}{l|}{ \% Vrouwen } \\
\hline & \multicolumn{1}{|l|}{1932} & \multicolumn{1}{l|}{1948} & 1932 & 1948 & 1932 & 1948 & 1932 & 1948 \\
\hline Aardewerk & 370 & 298 & 248 & 368 & 618 & 666 & $40 \%$ & $55 \%$ \\
\hline Sanitair & 271 & 421 & 104 & 3 & 375 & 424 & $28 \%$ & $7 \%$ \\
\hline $\begin{array}{l}\text { Algemene dienst/ } \\
\text { Niet in te delen }\end{array}$ & 167 & 372 & 7 & 25 & 174 & 397 & $4 \%$ & $6 \%$ \\
\hline Totaal & 808 & 1.091 & 359 & 396 & 1.167 & 1.487 & $31 \%$ & $27 \%$ \\
\hline
\end{tabular}

Bronnen: IISG, archief Nederlandse Vereniging van Fabrieksarbeiders(sters), arch.nr.00993, inv.nr. 47: De Sphinx, Société Céramique, NV Kristal Unie 1932: 'Personeel per 22 Januari '32'. Zie ook De Groot, Fabricage van verschillen, 269 (mijn berekening wijkt op onderdelen af); SHCL, archief Sphinx, EAN 1012, inv.nr. 829: Personeelslijst 1947-1950.

Andersom heeft de daling van het aandeel van vrouwen in het Interbellum en daarna te maken met de relatieve afname van de aardewerkproductie ten opzichte van de productie van sanitair, zoals toiletten en wastafels. Dat werd steeds meer het hoofdproduct van Sphinx, tot de aardewerkafdeling in 1969 werd gesloten. Aanvankelijk werden vrouwen ook bij taken in de sanitairproductie ingeschakeld, maar uit een overzicht uit 1948 blijkt dat er na de Tweede Wereldoorlog nauwelijks nog vrouwen in de sanitairafdelingen werkten (zie tabel 9). Door de introductie van transportbanden en vernismachines werden voorheen door vrouwen uitgevoerde werkzaamheden overbodig. Bij de sluiting van de aardewerkfabriek in 1969 konden de mannen in de sanitairfabriek worden herplaatst; voor de 200 vrouwelijke werkneemsters was dat niet mogelijk. ${ }^{61}$

De gevolgen van de sterke groei van de werkgelegenheid voor vrouwen in de aardewerkindustrie in de tweede helft van de negentiende eeuw voor de vrouwelijke arbeidsparticipatie in Maastricht komt duidelijk tot uiting in het aandeel van de vrouwelijke partners dat bij haar huwelijk opgaf een beroep uit te oefenen (grafiek 12). Terwijl hiervóór kon worden vastgesteld dat dit aandeel voor Limburg in die periode al hoger lag dan gemiddeld in Nederland als geheel (zie grafiek 3), blijkt uit grafiek 12 dat Maastricht daar nog aanzienlijk bovenuit kwam, met name in de periode van de grote uitbreiding van de vrouwelijke werkgelegenheid in de aardwerkindustrie in de laatste decennia van de negentiende eeuw. Limburgs 
aanvankelijke voorsprong op dit gebied kan dus niet alleen aan de grote arbeidsinzet van vrouwen in de landbouw worden toegeschreven, maar ook aan die in de Maastrichtse industrie.

Opvallend in grafiek 12 is ook het relatief hoge niveau van beroepsuitoefening door bruiden in de eerste helft van de negentiende eeuw. Die kan worden verklaard door het grote aantal dagloonsters dat toen al op de Maastrichtse arbeidsmarkt beschikbaar was. In zijn onderzoek naar het Boschstraatkwartier vlakbij de fabrieken van Regout heeft Thijs van Vugt laten zien dat in 1829 losse werklieden in die buurt verreweg de grootste beroepscategorie vormden met 34 procent bij de mannen en zelfs 42 procent bij de vrouwen. ${ }^{62}$ Van 'fabrieken' was toen nog geen sprake; die werden pas in 1834 opgericht. Ook in de beroepstelling van 1859, dus vlak vóór de grote uitbreiding van de fabrieken van Regout, werden er nog 464 dagloonsters in Maastricht geteld, tegen 230 glas- en aardewerksters. In latere beroepstellingen zijn de dagloonsters geheel verdwenen. Mijn conclusie is dat er al vóór de vestiging van de fabrieken van Regout een traditie van loonarbeid onder de Maastrichtse vrouwen bestond, waarop hij kon voortbouwen bij het werven van vrouwelijk personeel.

Grafiek 12. Het percentage bruiden met een beroepsvermelding in de huwelijksakten in Maastricht en Limburg, 1812-1932

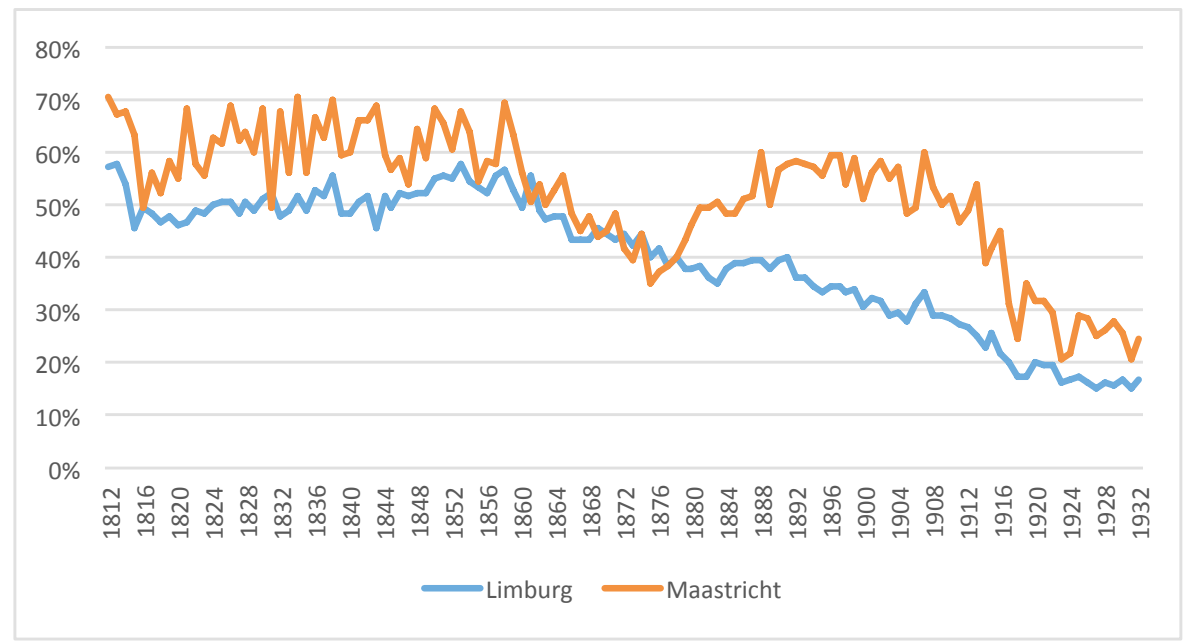

Bron: zie grafiek 3.

62 Van Vugt, Een arbeidersbuurt, 84-85. 
Die continuïteit komt mooi tot uiting in grafiek 13, waarin de beroepen van de bruiden zijn uitgesplitst naar dagloonsters en fabrieksarbeidsters enerzijds en glas- en aardewerksters anderzijds. In de eerste periode van groei van de fabrieken in de jaren 1860 en 1870 werden de vrouwen die in de fabrieken gingen werken nog in algemene zin dagloonster of fabrieksarbeidster genoemd; daarna werd de beroepsaanduiding specifieker. Het zeer hoge percentage glas- en aardewerksters onder de bruiden met beroepsvermelding in de laatste decennia van de negentiende eeuw tot en met 1914, met 72 procent in 1913 als hoogtepunt, toont aan dat het hoge niveau van Maastrichtse bruiden met een beroep in die periode, zoals bleek in grafiek 12, inderdaad aan de grote omvang van de vrouwelijke werkgelegenheid in die industrie kan worden toegeschreven. Opvallend in deze grafiek 13 is natuurlijk ook de scherpe terugval in de jaren 1920 en 1930, om precies te zijn na 1914, die samenvalt met de crisis in de glas- en aardewerkindustrie in die periode en de relatieve afname van het aandeel van vrouwen daarin. Ook de korte opleving aan het eind van de jaren 1920 komt treffend in deze grafiek tot uiting. Het geeft aan dat de beroepsopgaven in de huwelijksakten in dit geval wel degelijk een reëel beeld van de beroepsuitoefening door vrouwen geven en niet alleen uitdrukking zijn van een sociale norm.

Grafiek 13. Het percentage bruiden met beroepsvermelding in de Maastrichtse huwelijksakten werkzaam als dagloonster/fabrieksarbeidster en als glas- en aardewerkster, 1812-1941

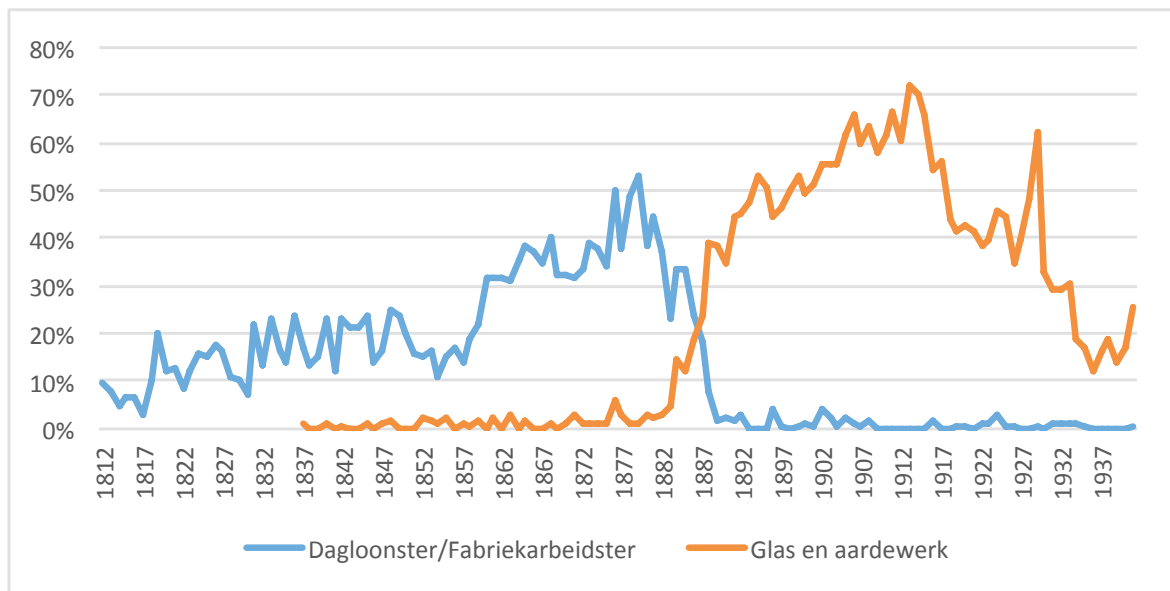

Bron:zie grafiek 3. 
De traditie van loonarbeid van vrouwen in Maastricht maakte het voor vrouwen vanzelfsprekend dat zij ook na hun huwelijk bleven werken. Uit het onderzoek naar de fabrieksarbeid van gehuwde vrouwen in Nederland uit 1909 blijkt dat die in Maastricht tot het hoogste van het land behoorde, zowel in absolute als in relatieve zin. ${ }^{63}$ Volgens het onderzoeksrapport maakte de 'groote uitgebreidheid van den vrouwenarbeid, die de geheele bevolking aldaar gewent aan het fabrieksleven, het begrijpelijk dat meerdere vrouwen na haar huwelijk den arbeid blijven voortzetten'. ${ }^{64}$ Elders in het rapport wordt een verband met de kinderarbeid geconstateerd: 'Evenals bij de glasfabrikage zijn de gehuwde arbeidsters [in de aardewerkfabrieken] voor het groote meerendeel van kind af aan den fabrieksarbeid gewoon. Er waren er 18 die reeds vóór het twaalfde jaar, één zelfs, die op haar $8^{\text {ste }}$ jaar daarmede begonnen waren'. ${ }^{65}$

Er was echter ook een economisch motief: 90 procent van de gehuwde vrouwen in Maastricht droeg meer dan 30 procent bij aan het gezinsinkomen (in het hele land was dat 87 procent). 'Onvoldoende verdiensten van de man' werd door 34 procent van de vrouwen genoemd als reden om na hun huwelijk te blijven werken (landelijk was dat 24 procent). ${ }^{66}$ Hoewel deze motivatie bij de ondervragers, en mogelijk ook bij de vrouwen zelf, een mannelijke kostwinnersnorm verraadt, kunnen wij er ook uit afleiden dat deze vrouwen substantieel bijdroegen aan de family wage economy. De vanzelfsprekendheid van arbeid door gehuwde vrouwen blijkt ook uit de inbedding in een familiaal netwerk van ondersteuning bij de gezinstaken. Die was in Maastricht sterker dan elders: 58 procent van de Maastrichtse vrouwen meldde dat zij hulp in de huishouding kregen van familieleden. Landelijk was dat slechts 29 procent. ${ }^{67}$

Dat de gehuwde vrouwen in de aardewerkindustrie hun eerder begonnen arbeid voortzetten, zoals door deze onderzoekers werd vastgesteld, was staand beleid in de fabrieken van de Regouts. Dat blijkt uit een antwoord van Louis Regout in de arbeidsenquête van 1887:

Getrouwde vrouwen worden bij ons in den regel niet aangesteld. Doch wanneer zij als meisje bij ons werkzaam zijn en zij trouwen, dan vinden wij geen reden om ze te bedanken; vandaar dat wij betrekkelijk zoveel getrouwde vrouwen op de fabriek hebben. Die vrouwen blijven hetzelfde werk verrichten dat zij als meisje deden [...]. ${ }^{68}$ 
Ook volgens hem was er voor de vrouwen een economisch motief om te blijven werken na hun huwelijk:

Zij verdient als vrouw ruim zoveel dat zij als meisje verdiend heeft, want zij is bedaarder geworden en heeft den goeden slag gekregen; dit is de tijd dat zij het beste werkt. Terwijl zij als meisje 60 cents verdiende, wordt het nu 80 cents en $f 1$ per dag, wat de vrouw missen zou als zij te huis bleef. ${ }^{69}$

Vanaf 1893 verbood de directie officieel om gehuwde vrouwen aan te nemen die voor hun huwelijk niet in de aardewerkfabriek hadden gewerkt, maar dit ver bod werd soepel toegepast. ${ }^{70}$ Het motief 'dit is de tijd dat zij het beste werkt', dat Louis Regout noemde als reden voor de vrouwen zelf om na hun huwelijk door te werken, was natuurlijk ook voor het bedrijf van belang: de ervaring die de vrouwen vóór hun huwelijk hadden opgedaan maakten hun arbeidsinzet daarna des te waardevoller. Vandaar dat de directie vooral belang hechtte aan het doorwerken van eerder aangenomen en inmiddels ingewerkte vrouwen. Om dat mogelijk te maken was het vrouwen toegestaan pasgeboren kinderen mee te nemen naar de fabriek om ze daar te verzorgen. Zo memoreerde het SDAP-raadslid Anna Wynandts-Louis in de jaren 1920 dat 'haar moeder van's morgens half zeven in de drukke tijden tot's nachts 12 uur in de fabriek moest werken, terwijl haar kind in een z.g. mand, in werkelijkheid was het een kist, naast haar lag en de algehele verzorging van het kind in de fabriek moest plaats hebben'. ${ }^{71}$ Maar daar was wel een grens aan, die vrij precies was bepaald op het krijgen van een derde kind. Voor de enquêtecommissie stelde Louis Regout het zo voor dat dit een soort gewoonte was:

Dat te huis blijven der vrouw heeft een gewonen gang, die vrij regelmatig is. Als zij twee kinderen hebben, beginnen zij zachtjes aan verlof te vragen om te huis te blijven; dan hebben zij een kind ziek, dan is er iets anders; en als zich dat wat herhaalt, zegt de opzichter vanzelf: Nu wordt het tijd, dat gij te huis blijft. ${ }^{72}$

ing en uitbreiding der wet van 19 september 1874 (Staatsblad no. 130) en naar den toestand van fabrieken en werkplaatsen (Sneek 1887) deel 2: Maastricht, 120, verhoor Louis Regout, antw. 6617, geciteerd in De Groot, Fabricage van verschillen, 279.

69 Geciteerd in ibidem, 280.

70 Ibidem, 281.

71 Geciteerd door J.J.G. Luijten, 'Anna-Cornelia Wynandts-Louis, eerste vrouwelijk raadslid van Maastricht en Nederland. Een glasslijpersfamilie in de greep van Regout', in: Ingrid M.H. Evers e.a. (red.), Bonne et servante. Uit de geschiedenis van de Maastrichtse vrouw (Maastricht 1986) 101-109, aldaar 101. 
In 1895 werd ook officieel door de bedrijfsleiding verordonneerd dat vrouwen na de derde bevalling niet meer aangenomen mochten worden. Ook dit gebod werd soepel toegepast al naar gelang de behoefte van het bedrijf aan arbeid door deze vrouwen. ${ }^{73}$ Niettemin kon Thijs van Vugt op basis van de personeelsadministratie van Sphinx vaststellen dat het werk van gehuwde vrouwen in de fabrieken afnam naarmate het huwelijk vorderde en er meer kinderen werden geboren. ${ }^{74}$

Het aandeel van de gehuwde vrouwen in het vrouwelijke personeelsbestand bij Sphinx was omstreeks 1895 op zijn hoogst: tussen de 26 en 29 procent (zie hiervóór, grafiek 10). In de jaren daarna werd dit met 20 tot 25 procent iets lager. Deze verhouding gold ook nog aan het eind van de jaren 1920 (23 procent in 1929), maar daarna nam het aandeel pijlsnel af tot slechts 3 procent in 1937 en de daaropvolgende jaren. De verklaring kan eenduidig worden gevonden in het personeelsbeleid van de directie van Sphinx:vooruitlopend op de invoering van betaald zwangerschapsverlof in de Ziektewet van 1930 besloot men met ingang van 1930 dat er geen gehuwde vrouwen meer werden aangesteld en dat 'elke werkneemster welke niet 5 jaren in dienst was, bij huwelijk ontslagen zou worden'. ${ }^{75}$ De Ziektewet bepaalde dat het loon van gehuwde vrouwen zes weken voor en zes weken na de bevalling moest worden doorbetaald. Blijkbaar vond de directie van Sphinx dat te duur, zoals blijkt uit een mededeling van directeur Bonemeyer uit 1930: 'De directie betreurt het [...] dat zij door de totstandkoming van wettelijke bepalingen, o.a. de Ziektewet, verplicht is geworden tot ontslag van gehuwde vrouwen'. ${ }^{76} \mathrm{De}$ katholieke fabrieksarbeidersbond Sint-Willibrordus, vurig aanhanger van de mannelijke kostwinnersnorm, stelde vast dat de Ziektewet

meer effect bleek te hebben dan alle sociale en zedelijke motieven welke in den loop der jaren tegen dit sociaal euvel [werkende gehuwde vrouwen] zijn aangevoerd. Want nu gehuwde vrouwen voor de Ziektewet dure objecten zijn geworden, werd in 1930 hier en daar het aantal gehuwde fabrieken verminderd, al gebeurt dit ook nog niet altijd op kiesche manier. ${ }^{77}$

Ibidem, 280-282.

74 Van Vugt, Een arbeidersbuurt, 154. Deze afname van loonarbeid door gehuwde vrouwen na een aantal jaren huwelijk was overigens een normaal verschijnsel in deze tijd: Ad Knotter, 'Gezinsarmoede-gezinsarbeid. De invloed van de gezinscyclus op de gezinnen van losse (haven)arbeiders in Amsterdam in de eerste helft van de twintigste eeuw', Tijdschrift voor Sociale Geschiedenis 24 (1988) 371-401. SHCL, archief Sphinx, EAN 1012, inv.nr. 723, Jaarverslag van de Sociale Afdeling, 1930. 
In de zowel door de katholieke als de socialistische fabrieksarbeidersbonden ondertekende CAO met Sphinx uit 1934 werd bepaald dat het sluiten van een huwelijk door een arbeidster een dringende reden tot onmiddellijk ontslag was. ${ }^{78}$ Sphinx verweet veel zwangere werkneemsters misbruik van het betaalde zwangerschapsverlof te maken. Van de 11 zwangere vrouwen in 1932 zou er slechts 'één, zegge één, na de bevalling hare plaats in de fabriek wederom' hebben ingenomen. 'In de andere gevallen dankten de dames voor de eer, doch niet voor het geld'. De personeelsafdeling concludeerde:

dat men uit een risico-oogpunt de gehuwde vrouw dient af te wijzen [...]. Ook dienen strenge orders gegeven te worden dat erop gelet wordt door die personen welke in de gelegenheid zijn het vrouwelijk personeel geregeld te observeren, dat ongehuwde werkneemsters bij welke zich bijzondere omstandigheden voordoen, tijdig heengezonden worden en niet een zevental maanden in het bedrijf rondlopen, waarna zij huwen om alsdan [...] wettelijke rechten te doen gelden en heengaan met het bekende ruim 100 gld. cadeau [...]. ${ }^{79}$

Waar dit toe leidde blijkt uit een interview dat Caspar Cillekens omstreeks 1980 afnam van een oud-werkneemster van Sphinx:

De Ziektewet was er pas door. Ik was voor de tweede keer in verwachting en toen moest ik op kantoor komen [...]: of ik er nog meer wist die in verwachting waren. Ik zeg: jullie hebben mij gekregen, maar een verrader ben ik niet, zoek ze maar zelf, van mij zal je niets [horen] [...]..$^{80}$

Omdat de directie had bepaald dat vrouwen met meer dan een vijfjarig dienstverband bij huwelijk niet hoefden te vertrekken, verliep de daling van het aantal gehuwde vrouwen in de fabriek geleidelijk. In 1933 waren er om die reden nog 23 vrouwen bij hun huwelijk in dienst gebleven, maar daarna daalde dit aantal van jaar op jaar tot dit in 1940 niet meer voorkwam. ${ }^{81}$ Om vervanging te vinden voor de gehuwde vrouwen moest Sphinx op zoek naar meer jonge ongehuwde vrouwen

78 IISG, archief Nederlandse Vereniging van Fabrieksarbeiders(sters), arch.nr.00993, inv.nr. 51: De Sphinx, Société Céramique, NV Kristal Unie: 'Collectieve arbeidsovereenkomst voor de N.V. Kristal-, Glas-en Aardewerkfabrieken “De Sphinx”, voorheen Petrus Regout \& Co. Te Maastricht'.

79 SHCL, archief Sphinx, EAN 1012, inv.nr. 723, Jaarverslag van de Sociale Afdeling, 1932; zie ook de verslagen over 1933, 1934 en 1935.

80 Geciteerd in Caspar Cillekens en Wil Roebroeks, Krisis in Maastricht. Werk en werkloosheid in de jaren dertig (Geulle 1983) 39.

81 SHCL, archief Sphinx, EAN 1012, inv.nr. 723, Jaarverslag van de Sociale Afdeling, 1932-1940. 
en meisjes. Omdat die bij huwelijk weer werden ontslagen nam ook de roulatie toe en werd de vraag nog groter. Sphinx vond dit nadeel blijkbaar minder groot dan het verlies aan ervaring van de gehuwden. De kostenfactor was hier doorslaggevend ${ }^{82}$

Dat was ook een argument om meisjes aan te stellen en deze niet te vervangen door jongens, hoewel daar in de jaren 1930 wel op werd aangedrongen en er in opdracht van de regering door de Arbeidsinspectie onderzoek naar werd gedaan. ${ }^{83}$ In het rapport van de Arbeidsinspectie daarover wordt over verschillende werkzaamheden in de Maastrichtse aardwerkfabrieken gesteld dat die evengoed door jongens zouden kunnen worden uitgevoerd, maar dat de 'de loonfactor aanleiding was tot't plaatsen van meisjes'. Het meisjesloon was 'op 20-jarige leeftijd niet voldoende voor een jongen'. De directie van een niet nader genoemde porseleinen aardwerkfabriek had bezwaren tegen de vervanging van meisjes door jongens omdat 'de loonen op oudere leeftijd onvoldoende zijn voor jongens en deze dan ontslag moeten krijgen indien ze niet kunnen opschuiven naar een andere afdeling'. Dat argument gold blijkbaar niet voor meisjes omdat die bij huwelijk werden ontslagen.

Het was echter niet zo gemakkelijk om voldoende meisjes en ongehuwde jonge vrouwen aan te trekken. In 1932 werd door de directie vastgesteld: 'Uit Maastricht zelf melden zich vrijwel geen vrouwen', en in 1934: 'Voor wat speciaal vrouwelijke werkkrachten betreft, hebben wij steeds kunnen constateeren dat het aanbod uit Maastricht niet voldoende was [...]'. Men trok daarom vrouwelijk personeel aan uit Belgische grensdorpen, met name uit Lanaken en omgeving, en ook 'meisjes van vreemde nationaliteit (Polen, Hongaren, Czechen en dergelijke) uit de Belgische mijnstreek'. ${ }^{84}$ Vanaf juli 1939 werd er intensief geworven in de Nederlandse mijnstreek, met als resultaat dat er in dit en volgende jaren elk jaar tussen de 100 en 150 zogenoemde 'mijnstreek-meisjes' konden worden aangesteld. De personeelsafdeling van Sphinx ging ervan uit dat Belgische en 'mijnstreek-meisjes' blijvend 30 à 35 procent van de vrouwelijke arbeidsbezetting zouden vormen. ${ }^{85}$ In de jaren 1950 liepen de aanmeldingen uit de mijnstreek echter sterk terug, omdat daar steeds meer werkgelegenheid kwam voor meisjes tegen een vergelijkbaar loon, bijvoorbeeld bij de recent gevestigde Philipsfabriek of bij de tricotageateliers. ${ }^{86}$

82 Vgl. De Groot, Fabricage van verschillen, 239-240, 246-247.

83 RHCL, archief Eerste District van de Arbeidsinspectie te Maastricht, 07.G05, inv.nr. 11: Stukken betreffende het onderzoek naar arbeid door vrouwen en meisjes in de industrie, 1933-1935. Zie ook De Groot, Fabricage van verschillen, 240.

84 Geciteerd door ibidem, 283-284.

85 SHCL, archief Sphinx, EAN 1012, inv.nr. 723, Jaarverslag van de Sociale Afdeling, 1939-1944.

86 Ibidem, 1954. 


\section{Conclusie: een stille revolutie}

De uitstoting van gehuwde vrouwen uit het arbeidsproces door Sphinx in de jaren 1930 was niet direct bedoeld om de effectiviteit van de wederzijdse arbeidsinzet van de huwelijkspartners in het mannelijke kostwinnersgezin te vergroten, maar viel wel samen met een reorganisatie en vernieuwing van de bedrijfsvoering die men 'Fordistisch' zou kunnen noemen. Met de overgang naar sanitair als hoofdproduct, de rationalisering van de productie door de concentratie daarvan in het nieuwgebouwde Eiffelgebouw, de ingebruikneming van de veel efficiëntere tunnelovens, de verwetenschappelijking van de techniek, de wijzigingen in de arbeidsorganisatie die daarmee gepaard ging, en last but not least de normalisering van de arbeidsverhoudingen door nu eindelijk een collectieve arbeidsovereenkomst te sluiten, nam de bedrijfsleiding van Sphinx in deze jaren op tal van terreinen afscheid van de negentiende-eeuwse manier van werken. ${ }^{87}$ Het terugdringen van de arbeid door vrouwen - gehuwd en ongehuwd - past hierin.

De 'stille revolutie' in de vrouwelijke arbeidsparticipatie in Limburg is in de Maastrichtse aardewerkfabrieken niet alleen zichtbaar in de daling van het aandeel van vrouwen en de verwijdering van gehuwde vrouwen uit het arbeidsproces, maar ook in de manier waarop daarna jonge vrouwen werden ingezet, namelijk alleen als tijdelijke en roulerende arbeidskrachten. Het hoogtepunt van de vrouwelijke arbeidsinzet in Maastricht viel samen met de bloeitijd van de aardewerkindustrie tussen circa 1880 en 1915 . In de jaren daarna verloor de vrouwenarbeid in de fabrieken als vaste waarde steeds meer terrein. De aard van die arbeid veranderde:aanvankelijk kon de entree van vrouwen in de fabrieken op jonge leeftijd een opstap zijn naar een meer ervaren beroepsuitoefening op latere leeftijd, al of niet in gehuwde staat, maar in de jaren 1930 werd dit opgegeven voor een roulerende tewerkstelling van meisjes aan wie geen verder loopbaanperspectief in het vooruitzicht werd gesteld. Dat deze meisjes voor een aanzienlijk deel uit de mijnstreek moesten worden gerekruteerd is niet toevallig. Door de eenzijdige samenstelling van de werkgelegenheid in de mijnindustrie, die alleen aan mannen werk bood, bestond er daar een groot tekort aan arbeidsplaatsen voor meisjes en jonge vrouwen, vooral mijnwerkersdochters, maar alleen zolang zij niet als gehuwde vrouwen hun noodzakelijke reproductieve rol in de mijnwerkersgezinnen konden opnemen. De roulerende arbeidsvraag bij Sphinx in Maastricht vond daarom zijn pendant in de eenzijdig voor arbeid door mijnwerkersdochters ingerichte confectie- en tricotage-

87 Deze gelijktijdig optredende veranderingsprocessen worden beschreven in verschillende bijdragen in Ad Knotter (red.), Keramiekstad. Maastricht en de aardewerkindustrie in de negentiende en twintigste eeuw (Zwolle/Maastricht 2016). 
ateliers in de beide mijnstreken. Op deze manier werd het mannelijke kostwinnersgezin zowel in de mijnstreken als in Maastricht in stand gehouden dan wel versterkt.

In grafiek 2 (zie hiervóór) bleek dat er in Limburg als geheel tot en met de beroepstelling van 1909 een - zij het beperkte - oververtegenwoordiging van vrouwen in de industrie bestond. Die kan grotendeels worden toegeschreven aan de sterke aanwezigheid van vrouwen in de Maastrichtse glas- en aardewerkfabrieken. De ondervertegenwoordiging van vrouwen in de industrie in de beroepstellingen daarna is echter niet alleen een gevolg van de daling van het aandeel van vrouwen in deze bedrijfstak, maar vooral van de groei van de werkgelegenheid in mijnbouwsector, waarin het mannelijke kostwinnersgezin overheerste. In de mijnstreken was de vrouwelijke arbeidsparticipatie veel lager dan in andere gebieden van Limburg, met name daar waar het boerengezinsbedrijf overheerste. De 'stille revolutie' in de vrouwelijke arbeidsparticipatie in Limburg is daarom allereerst een statistisch gevolg van de snelle opkomst van de mijnindustrie in de periode tussen de beroepstellingen van 1909 en 1930 en de relatieve afname van de landbouw als middel van bestaan.

Het is tekenend voor de veerkracht - of zo men wil inertie - van het boerengezinsbedrijf met zijn grote inzet van vrouwelijke arbeidskracht dat dit tot na de Tweede Wereldoorlog bleef zorgen voor een Limburgse voorsprong in de vrouwelijke arbeidsparticipatie, zij het in afnemende mate (zie hiervóór grafiek 1). De omslag in de jaren 1950 was weliswaar minder abrupt dan de beroepstelling van 1960 suggereert, maar in de jaren 1950 en 1960 nam het aantal vrouwelijke arbeidskrachten in de landbouw wel af. Deze afname ging gepaard met een verschuiving die tegengesteld was aan die in de Maastrichtse industrie en de mijnwerkersgezinnen: de rol van de boerin als meewerkende echtgenote werd sterker, die van de in het gezinsbedrijf werkende boerendochters verdween. Ook hier vond dus een dubbele evolutie plaats: de afname van de vrouwenarbeid ging gepaard met een verschuiving wat betreft de huwelijkse staat en de leeftijdsopbouw van de werkende vrouwen in de landbouw, maar dan in omgekeerde zin.

Mijn bevindingen in Limburg ondersteunen de conclusie in het recente proefschrift van Corinne Boter, dat een verklaring voor de opkomst van het mannelijke kostwinnersgezin niet alleen aan de aanbodzijde (het hoge mannelijke loonpeil), maar ook aan de vraagzijde van de arbeidsmarkt voor vrouwen moet worden gezocht. Er waren grote verschillen in de ontwikkeling per bedrijfstak en sector, met als tegenpolen de mijnbouw, die bij uitstek steunde op het mannelijke kostwinnersmodel met als gevolg een lage vrouwelijke arbeidsparticipatie, en de landbouw, die werd beheerst door boerengezinsbedrijven met een grote inzet van vrouwelijke arbeidskracht. De Maastrichtse industrie kende dan weer een eigen ontwikkeling. 
De uitwerking van deze verschillen op de economische gezinsstructuur, waar het in de discussie over de opkomst van het mannelijke kostwinnersgezin in feite om gaat, kan niet eenduidig worden geplaatst in de klassieke categorisering van Tilly en Scott, die een evolutie zagen van family economy via family wage economy naar family consumer economy. Door de inzet van echtgenotes in het boerengezinsbedrijf bleef dat trekken van de family economy behouden, maar voor zover de boerenzoons en -dochters hun elders verdiende loon aan hun ouders moesten afstaan, zoals nog tot ver in de jaren 1960 gebruikelijk was, is hier ook sprake van een family wage economy. Dat laatste geldt natuurlijk ook voor de inkomsten van zoons en dochters in mijnwerkersgezinnen, hoewel die gezien de eenzijdige huishoudelijke arbeid van de mijnwerkersvrouw als family consumer economy zouden kunnen worden beschouwd.

Ik meen hiermee, tot slot, te hebben aangetoond dat het interessant en belangrijk is om de rol van vrouwen in de geschiedenis apart te onderzoeken. Geheel ten overvloede concludeer ik dat het genderperspectief een noodzakelijke correctie betekent op de bestaande androcentrische geschiedschrijving van arbeid en beroep, waaronder die van mijzelf. ${ }^{88}$

\section{Dankwoord en enkele overwegingen bij mijn afscheid}

Deze rede had niet, of veel moeilijker, geschreven kunnen worden als ik niet heel dicht had gewerkt bij de bronnen die bewaard worden door het Sociaal Historisch Centrum voor Limburg. Ik neem vandaag ook afscheid als directeur van het SHCL en ik kan niet genoeg benadrukken hoe gelukkig de combinatie van onderzoek-en documentatiecentrum is. Die combinatie heeft mij in de afgelopen 20 jaar in staat gesteld veel nieuw onderzoek te doen en te publiceren. Dat geldt niet alleen voor mijzelf, maar ook voor andere aan het Centrum verbonden onderzoekers, van wie met name hoofd onderzoek en adjunct-directeur Willibrord Rutten met ere genoemd moet worden. De instandhouding van de combinatie van onderzoek en collectievorming lijkt gewaarborgd in de aanstaande integratie van ons werk in het Historisch Centrum Limburg. Ik hoop dat onze opvolgers zullen ervaren en herkennen hoe belangrijk dit is en hoe bevoorrecht zij zijn om in dit laboratorium voor historisch onderzoek te kunnen werken. 
Ik ben indertijd aangesteld als directeur-hoogleraar omdat ik naast wetenschappelijke kennis op het gebied van de regionale geschiedenis ook ervaring had met het beheren van archieven. Ik was afkomstig van het Gemeentearchief Amsterdam, waar de combinatie van wetenschappelijk onderzoek en archiefzorg toen nog mogelijk was. Deze combinatie kon het SHCL in 1998 goed gebruiken, omdat er op het terrein van de archiefzorg een forse inhaalslag noodzakelijk was. Ik beschouw het zelf als mijn grootste verdienste als directeur dat wij er onder mijn eindverantwoordelijkheid in zijn geslaagd de archieven van het SHCL grotendeels op orde te brengen. Ik kijk met grote waardering terug op alle personeelsleden die dit project hebben uitgevoerd en mogelijk gemaakt. Van hen wil ik in het bijzonder noemen Hans van Hall, Andrea Peeters, Dirk van de Leemput en Herman Wijenberg. Voor de bibliotheek van het SHCL was zo'n inhaalslag niet nodig, dankzij de professionaliteit van ons bibliotheekteam dat al vóór mijn komst aan de slag was.

Heel veel plezier heb ik ook beleefd aan het doen, het stimuleren, en het begeleiden van wetenschappelijk onderzoek, inclusief het redactiewerk voor het klaarmaken van onze publicaties. Het SHCL beschikt over een uitstekend bemenst en soepel opererend apparaat om uitgaven voor te bereiden en vorm te geven. Elk jaar kwam er weer een jaarboek van het SHCL uit en één of meer delen in de reeks Maaslandse Monografieën, naast incidenteel andere uitgaven die er steeds mooier uit gingen zien. Paul Arnold, Ella Muyres en opnieuw Willibrord Rutten waren hiervoor verantwoordelijk.

Uiteindelijk draait echter alles om de inhoud van het onderzoek. Ik ben niet behept met enig Limburg-gevoel en dat is dan ook nooit leidraad of motivatie geweest om in deze streken historisch onderzoek te doen. Wel heeft de ligging van Limburg, met internationale verbindingen naar alle kanten, voor mijn gevoel iets bijzonders toegevoegd aan mijn historisch bewustzijn: mijn mental map en geografische scoop zijn heel anders geworden dan in mijn Amsterdamse tijd. De 'vergelijkende regionale geschiedenis' in mijn leeropdracht kon ik grensoverschrijdend vormgeven in het brede gebied tussen Lille in Noord-Frankrijk en Bochum in het Ruhrgebied, aan de uiteinden van het vroegere industriële kerngebied van West-Europa, nu een soort Europese Rustbelt. Ik denk met veel genoegen terug aan de vele internationale wetenschappelijke contacten die ik in dit kader heb kunnen onderhouden en de wetenschappelijke samenwerking over de grenzen heen die daarvan het gevolg was. Het meest productief was wel die met Peter Scholliers van de Vrije Universiteit Brussel, die onder meer tot twee promoties heeft geleid. De grensoverschrijdende oriëntatie van mijn leeropdracht brachten mij ook tot transnationaal en vergelijkend regionaal onderzoek op ruimer Europese en zelfs mondiale schaal. 
Het is niet aan mij om een oordeel uit te spreken over mijn verdiensten op regionaal-historisch gebied. Ik hecht zelf belang aan bijdragen op drie terreinen. Ten eerste mijn kritiek op het idee van een Kulturraum Maas-Rijn en de bijbehorende mythe van een 'land zonder grenzen'. ${ }^{89}$ Limburg maakt deel uit van een grensgebied en die grenzen kan je niet wegdenken uit de geschiedenis. Onder de naam 'historische grensstudies' heb ik de sociale, economische en culturele effecten van de grensligging van Limburg als uitgangspunt van onderzoek genomen. Ten tweede mijn kritiek op essentialistische opvattingen over de zogenaamde Limburgse identiteit. Het ontstaan van het Limburggevoel is onlosmakelijk verbonden met de incorporatie van Limburg in het Nederlandse staatsverband in de negentiende eeuw. Vandaar ook dat het idee van de eenheid van beide Limburgen in de praktijk niet werkt..$^{90}$ Ten derde heb ik samen met anderen geprobeerd de sterke morele lading die de geschiedschrijving van het mijnverleden in Limburg had en heeft te overstijgen door nuchter objectiverend onderzoek. De voorzitter van de Stichting 'De Koempel Verhaalt', oud-aalmoezenier Jos Schreurs, vond in 2012 dat het door ons in opdracht van die Stichting geschreven boek Mijnwerkers in Limburg: een sociale geschiedenis vooral moest bijdragen aan het 'eerherstel' van de mijnwerkers vanwege hun 'onrechtvaardige behandeling' in het verleden. ${ }^{91}$ Of geschiedschrijving daarvoor het meest geëigende middel is waag ik te betwijfelen; het is in ieder geval nooit de inzet van de auteurs geweest.

Rest mij mijn grote dank uit te spreken aan al diegenen die mijn en ons werk op het Sociaal Historisch Centrum hebben mogelijk gemaakt. Ik noem allereerst de opeenvolgende besturen waaronder ik heb gediend, onder voorzitterschap van Hein van der Bruggen, Gerard van der Velde en Harry Hillen. Wij hebben gezamenlijk heel wat stormen doorstaan, met name in de relatie met de Provincie Limburg. Gelukkig is dit uiteindelijk in positieve zin opgelost. Ik dank ook de

89 Vgl. Ad Knotter, 'Paradoxen van de grens. Ongelijke ontwikkeling, grensoverschrijdende mobiliteit en de vergelijkende geschiedenis van de Euregio Maas-Rijn', Studies over de sociaal-economische geschiedenis van Limburg/Jaarboek van het Sociaal Historisch Centrum voor Limburg XLVI (2001) 159-174; idem, 'Na de Kulturraumforschung. Oude en nieuwe concepten in de grensoverschrijdende regionale geschiedschrijving', Tijdschrift voor Geschiedenis 118 (2005) 227-246; idem, 'Inleiding', in: Berkvens e.a. (red.), Limburg: een geschiedenis, deel I, 17-25.

90 Ad Knotter, 'Limburg bestaat niet. Paradoxen van een sterke identiteit', Bijdragen en Mededelingen betreffende de Geschiedenis der Nederlanden / The Low Countries Historical Review 123 (2008) 354-367; herdrukt in idem (red.), Dit is Limburg! Opstellen over de Limburgse identiteit (her)uitgegeven ter gelegenheid van het zestigjarig bestaan van het Sociaal Historisch Centrum voor Limburg (Zwolle/Maastricht 2009) 263277; idem, ' 175 jaar beide Limburgen:waarom ze toch niet bij elkaar horen', De Maasgouw. Tijdschrift voor Limburgse geschiedenis en oudheidkunde 134 (2015) 5-11; Leonie Cornips en Ad Knotter, 'De uitvinding van Limburg: de territorialisering van geschiedenis, taal en identiteit', Studies over de sociaaleconomische geschiedenis van Limburg/Jaarboek van het Sociaal Historisch Centrum voor Limburg LXI (2016) 136-163.

91 Knotter (red.), Mijnwerkers in Limburg. 
besturen en directies van het Regionaal Historisch Centrum Limburg, waar wij sinds 2008 zijn gehuisvest en met wie wij een mooie toekomst tegemoet gaan. Mijn grootste dank gaat echter uit naar de Universiteit Maastricht. Opeenvolgende Colleges van Bestuur en besturen en decanen van de Faculteit der Cultuur-en Maatschappijwetenschappen hebben mij, en daarmee het SHCL, door dik en dun gesteund. Wat dat betreft was er een vertrouwenwekkende continuïteit van beleid van Karl Dittrich tot en met Nick Bos in het CvB en van Wiebe Bijker, Paul Tummers en Rein de Wilde tot en met Sophie Vanhoonacker als decanen van de Faculteit. Deze ervaring geeft mij het volste vertrouwen in de op te richten academische werkplaats in het toekomstige Historisch Centrum Limburg, waarin het wetenschappelijke werk van het SHCL onder verantwoordelijkheid van de Faculteit zal worden voortgezet.

Ik heb gezegd. 


\section{Bijlage 1. Het percentage vrouwen met een beroepsvermel- ding in clusters van landbouwdorpen in Midden-Limburg en het Heuvelland, mijngemeenten in de Oostelijke en Weste- lijke Mijnstreek, en Maastricht, 1909-1960}

\begin{tabular}{|l|r|r|r|r|r|}
\hline Geselecteerde gemeenten & \multicolumn{1}{|l|}{1909} & 1930 & 1947 & 1960 & 1971 \\
\hline Dorpen in Midden-Limburg ten westen van de Maas* & $32 \%$ & $31 \%$ & $27 \%$ & $14 \%$ & $19 \%$ \\
\hline Dorpen in het Heuvelland ten oosten van Maastricht* & $33 \%$ & $29 \%$ & $30 \%$ & $14 \%$ & $15 \%$ \\
\hline Maastricht & $26 \%$ & $23 \%$ & $18 \%$ & $17 \%$ & $19 \%$ \\
\hline Mijngemeenten in de Oostelijke Mijnstreek* & $15 \%$ & $11 \%$ & $14 \%$ & $14 \%$ & $18 \%$ \\
\hline Mijngemeenten in de Westelijke Mijnstreek* & $18 \%$ & $12 \%$ & $17 \%$ & $13 \%$ & $17 \%$ \\
\hline Limburg & $22 \%$ & $18 \%$ & $19 \%$ & $15 \%$ & $18 \%$ \\
\hline
\end{tabular}

NB 'Percentage vrouwen met een beroep' gedefinieerd als het aantal vrouwen met een geteld beroep ten opzichte van de totale vrouwelijke bevolking.

* Zie tabel 2.

Bronnen: 1909: CBS, Uitkomsten der Beroepstelling [...] 1909; 1930: SHCL, archief Economisch-Technologisch Instituut in Limburg (ETIL), inv.nrs. 923-926: Staten van CBS-gegevens over de bevolking per Limburgse gemeente [1930 en 1947]; 1947-1971: SHCL:Collectie CBS-statistieken, BH 1.1: Uitkomsten van de volks-en beroepstelling 31 mei 1947 per gemeente van de provincie Limburg; BH 1.2: Uitkomsten van de $13^{\mathrm{e}}$ algemene volkstelling, 31 mei 1960, deel 6: Limburg; BH 1.3:14e algemene volkstelling annex woningtelling 28 februari 1971: definitieve uitkomsten per Limburgse gemeente. 


\section{Kopijverzorging:}

Sociaal Historisch Centrum voor Limburg

\section{Fotoreproductie:}

Sociaal Historisch Centrum voor Limburg

\section{Omslag en typografie:}

\section{Lori Lenssinck}

\section{COLOFON}

Uitgave

WBOOKS, Zwolle

info@wbooks.com

www.wbooks.com

i.s.m.

Sociaal Historisch Centrum voor

Limburg, Maastricht

Info-shcl@maastrichtuniversity.nl

www.shclimburg.nl

(C) 2018 Sociaal Historisch Centrum voor Limburg / Ad Knotter
Alle rechten voorbehouden. Niets uit deze uitgave mag worden verveelvoudigd, opgeslagen in een geautomatiseerd gegevensbestand, of openbaar gemaakt, in enige vorm of op enige wijze, hetzij elektronisch, mechanisch, door fotokopieën, opnamen of op enige andere wijze, zonder voorafgaande schriftelijke toestemming van de uitgever.

De uitgever heeft ernaar gestreefd de rechten met betrekking tot de illustraties volgens de wettelijke bepalingen te regelen. Degenen die desondanks menen zekere rechten te kunnen doen gelden, kunnen zich alsnog tot de uitgever wenden.

Van werken van beeldende kunstenaars aangesloten bij een CISAC-organisatie is het auteursrecht geregeld met Pictoright te Amsterdam.

(C) c/o Pictoright Amsterdam 2018.

ISBN 9789462583085

NUR 696 


\section{Foto cover}

Het Fonds voor Sociale Instellingen van Staatsmijnen opende begin jaren 1930 enkele confectieateliers voor mijnwerkersdochters. Hier een kijkje in het atelier voor regenkleding in Terwinselen, 1936. RHCL, fotocollectie Staatsmijnen/DSM.

\section{Foto binnenkant omslag voor}

Een werkploeg op de vernisafdeling van de Sphinx aardewerkfabriek, ca. 1930. Op deze foto wordt de dompelmethode gehanteerd, waarbij de man het ruwe aardewerk met de hand in een glazuurbad dompelt. Hij wordt geassisteerd door vrouwelijke hulpen. SHCL, fotocollectie Sphinx-Céramique.

\section{Foto binnenkant omslag achter}

Een boerin plant jonge spruitkoolplantjes in de moestuin, ca.

1960. SHCL, fotocollectie Zij-Actief. 


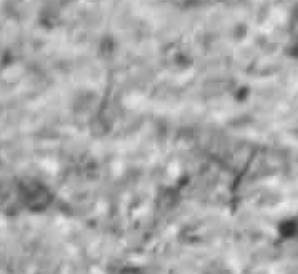

4

6. $8 x^{2}+b^{2}$

$\frac{1}{4}=2$

yidition

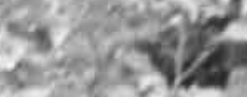

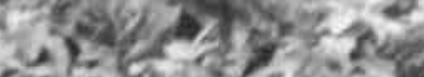

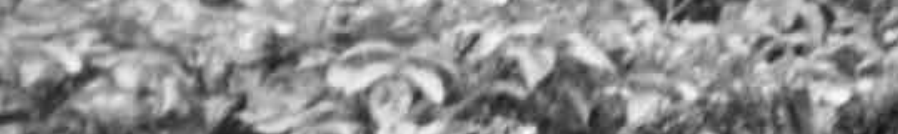

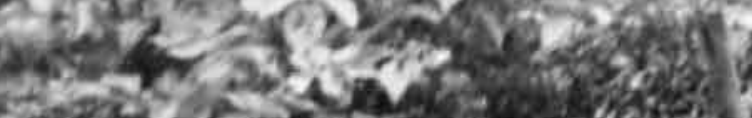

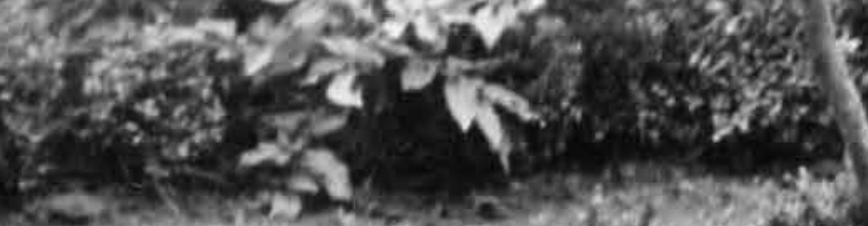

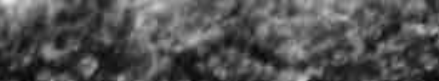

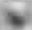

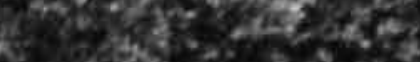

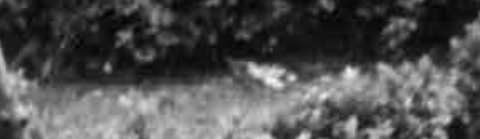
cheris

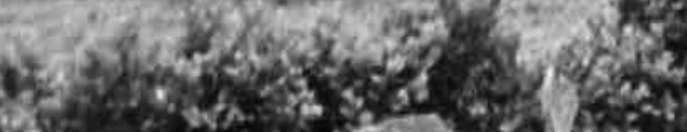

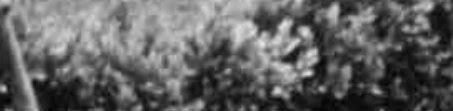

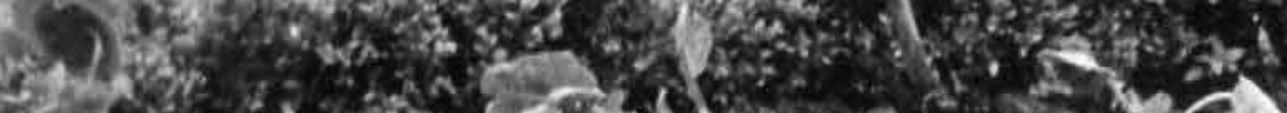

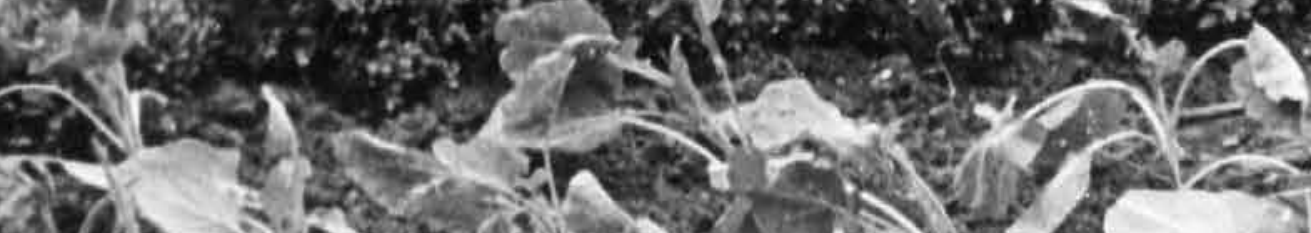



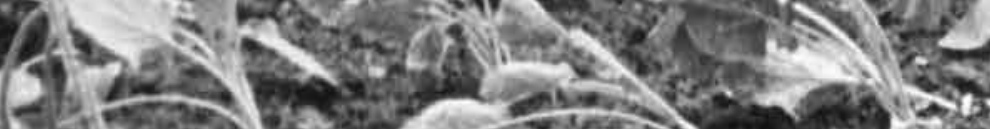
ar?

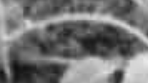
क्ष. 